\title{
Fossil calibrations for the cockroach phylogeny (Insecta, Dictyoptera, Blattodea), comments on the use of wings for their identification, and a redescription of the oldest Blaberidae
}

\author{
Dominic A. Evangelista, Marie Djernæs, and Manpreet Kaur Kohli
}

\begin{abstract}
Here we provide the first thorough assessment of the fossil calibrations for divergence time estimation of cockroaches. Through a review of published fossil descriptions, we evaluate oldest fossils for various nodes in crown Blattodea in accordance with recently proposed best practices. Since most descriptions of fossil cockroaches rely heavily on wing and tegminal venation, we also provide a critical assessment of Rehn (1951), which is the most extensive work on these characters. We find that Rehn (1951) incorrectly reported the state of numerous characters. This, combined with the low number of informative characters in cockroach wings, negatively affects phylogenetic justifications of some of the oldest purported fossil cockroaches. We conclude that currently the best fossils to use for calibration of the cockroach tree are: Cretaholocompsa montsecana, "Gyna" obesa, Cariblattoides labandeirai, and Ectobius kohlsi. One of these, "Gyna" obesa, was insufficiently treated in its original description, so we provide a redescription facilitated by high resolution imagery and modern systematic knowledge. We comment on the difficulty of utilizing the so-called fossil roachoids because their position at the base of Dictyoptera is under dispute and cannot be reliably verified. We do not include calibrations for termite lineages.
\end{abstract}

Dominic A. Evangelista, Muséum National d'Histoire Naturelle, 45 Rue Buffon CP50, Paris, France 75005. DominicEv@gmail.com

Marie Djernæs. Natural History Museum, Cromwell Road, London SW7 5BD, United Kingdom. marie_djernaes@hotmail.com

Manpreet Kaur Kohli. Rutgers University, 195 University Ave, Newark, NJ, USA 07102. mkk24@njit.edu

Evangelista, Dominic A., Djernæs, Marie, and Kohli, Manpreet Kaur. 2017. Fossil calibrations for the cockroach phylogeny (Insecta, Dictyoptera, Blattodea), comments on the use of wings for their identification, and a redescription of the oldest Blaberidae.

Palaeontologia Electronica 20.3.1FC: 1-23

palaeo-electronica.org/content/fc-10

Copyright: September 2017 Paleontology Society. This is an open access article distributed under the terms of AttributionNonCommercial-ShareAlike 4.0 International (CC BY-NC-SA 4.0), which permits users to copy and redistribute the material in any medium or format, provided it is not used for commercial purposes and the original author and source are credited, with indications if any changes are made.

creativecommons.org/licenses/by-nc-sa/4.0/

Calibrations published in the Fossil Calibration Series are accessioned into the Fossil Calibration Database (www.fossilcalibrations.org). The Database is a dynamic tool for finding up-to-date calibrations, and calibration data will be updated and annotated as interpretations change. In contrast, the Fossil Calibration papers are a permanent published record of the information on which the calibrations were originally based. Please refer to the Database for the latest data. 
Keywords: Phylogenetics; morphology; dating; divergence; systematics; paleoentomology

\section{INTRODUCTION}

Molecular phylogenetic studies of cockroaches go back more than 20 years (Kambhampati et al., 1996), but molecular dating of cockroach phylogenies has only begun recently (Djernæs et al., 2015; Legendre et al., 2015; Che et al., 2017). One of the crucial points in divergence time estimation is choosing the correct fossils for age calibration, as these are highly influential on posterior age estimates (e.g., Inoue et al., 2010). However, abundance of plesiomorphic, homoplastic, or highly derived morphological characters impedes accurate identification and phylogenetic placement of fossils, making selection of fossils as calibration points a challenging task.

There have been three molecular phylogenies of Blattodea with fossil-calibrated divergence dates (Djernæs et al., 2015; Legendre et al., 2015; Che et al., 2017), not including those focusing on termites (e.g., Ware et al., 2010). Some studies with larger scope have dated nodes within Dictyoptera as well (Misof et al., 2014; Tong et al., 2015). Djernæs et al. (2015) dated their tree with one fossil termite (Meiatermes bertrani Lacasa Ruiz and Martínez-Delclòs 1986), one stem Mantodea (Homocladus grandis Carpenter, 1966), one fossil mantis (Prochaeradodis enigmaticus Piton, 1940), and did not include any Blattodea fossils in their analysis. The most comprehensive dictyopteran phylogeny (Legendre et al., 2015) used 17 fossils as calibration points following the best practices suggested by Parham et al. (2012). Four of these fossil calibration points were non-termite crown Blattodea, and we evaluate each of these in the current paper. Most recently, Che et al. (2017) used five fossil Blaberoidea to date their $\mathrm{CO}$ gene tree. We briefly discuss four of these (Piniblattella, Epilampra sp., Pycnoscelus gardneri, Zetobora brunneri) here but do not agree with any of them as calibration points because of their poor phylogenetic justifications. One (Supella miocenica) is a comparatively recent fossil, and we do not assess its utility.

Dates for the split between Mantises and cockroaches vary from 300-200 Ma (300 Ma: Legendre et al., 2015, Béthoux and Wieland, 2009; 275 Ma: Djernæs et al., 2015; 250 Ma: Ware et al., 2010; $225 \mathrm{Ma}$ : Tong et al., 2015; and $200 \mathrm{Ma}$ Misof et al., 2014). Dates for the split of crown Blat- todea into Blattoidea and Blaberoidea (sensu Beccaloni and Eggleton, 2013) also vary between 275 (Legendre et al., 2015) and 180 Ma (Misof et al., 2014; Tong et al., 2015). There is no convergence toward a single timing for these important splits, although all the dates fall between the early Permian (300 Ma) and late Jurassic (150 Ma).

The current paper aims to provide a list of extensively vetted fossils that can be used for calibrating molecular phylogenies of cockroaches. Cockroaches, like other groups, are rarely preserved perfectly in impression or amber fossils, leaving a paucity of morphological characters for their taxonomic placement. Genitalia, which are among the most phylogenetically informative characters for cockroaches (Roth, 1970; Grandcolas, 1996; Klass, 1997; Klass, 2001; Klass and Meier, 2006), are rarely discernible in cockroach impression fossils. The most commonly preserved features are wings, usually the more sclerotized front wings (tegmina) (e.g., Anisyutkin et al., 2008; Vršanský, 2008). Unfortunately, morphological characters in the wings typically do not give a strong indication of taxonomic identity due to the abundance of plesiomorphic and homoplastic characters (discussed in Klass, 2001; Ross, 2012; Djernæs et al., 2015; pers. obs. based on data from Rehn, 1951). Furthermore, many tegminal characters are not uniform within a single species or even a single individual. Ross (2012) did an extensive study of cockroach forewing variation where he found: variation in vein number within a single individual is commonplace (>90\% of individuals in Blattella germanica), vein number is dependent on variation in wing size, number of veins in the $\mathrm{M}$ and $\mathrm{CuA}$ are inversely correlated and highly variable, and tegmina shape and color patterns are reliable characters (Ross, 2012; Lee, 2016). Béthoux and Wieland (2009) proposed that veins can be translocated to nearby locations on a wing, and data on the tegminal $\mathrm{M}$ and $\mathrm{CuA}$ vein from Ross (2012) suggests that such translocations are commonplace in intraspecific variation. For these reasons, fore-wings are not heavily relied upon in taxonomic studies treating extant taxa (e.g., Lopes and Da Silva, 2013; Vidlička, 2013; Wang et al., 2013; Evangelista et al., 2015; Silva-da-Silva and Lopes, 2015; Evangelista et al., 2016).

Fortunately, there are a few cases where bodies with diagnostic characters have been pre- 
served in amber or impression fossils (e.g., Shelford, 1910; Vršanský et al., 2014). Age calibrations can be reliable if they utilize fossils such as these. In this paper we extensively vet the oldest crown cockroach fossils to be used as calibration points for extrapolations of node age on molecular phylogenies. We use the best practices as outlined by Parham et al. (2012) as criteria for accepting or rejecting fossils, as well as a review of wing morphological characters (Rehn, 1951) to assist with supporting phylogenetic justifications. For one fossil, "Gyna" obesa (Piton, 1940), we provide a redescription.

\section{METHODS}

The goal of this paper is to calibrate major nodes on the phylogeny of Blattodea. We only calibrated crown nodes with strong phylogenetic sup- port and not the possible stem families of Blattodea or Dictyoptera. We only evaluated the accuracy and potential reliability of fossils purported to be members of crown lineages of Blattodea. However, we did not treat any termites.

The nodes we chose to calibrate correspond to well-supported clades that have strongly justified fossils that fall within them. We synthesized a phylogeny (Figure 1) of Blattodea based on previous studies (figure 2 in Maekawa et al., 2003; figure 4 in Klass and Meier, 2006; figure 1 in Inward et al., 2007; figure 3 in Pellens et al., 2007; figure 2 in Murienne, 2009; figure 2 in Djernæs et al., 2012; figure 3 in Djernæs et al., 2015; figures 4, 5, and 6 in Legendre et al., 2015) to determine the placement of our fossils (Figure 2). This also reinforces our assumptions about the monophyly of the groups we calibrated. The process we used for synthesizing this tree involved obtaining contextual

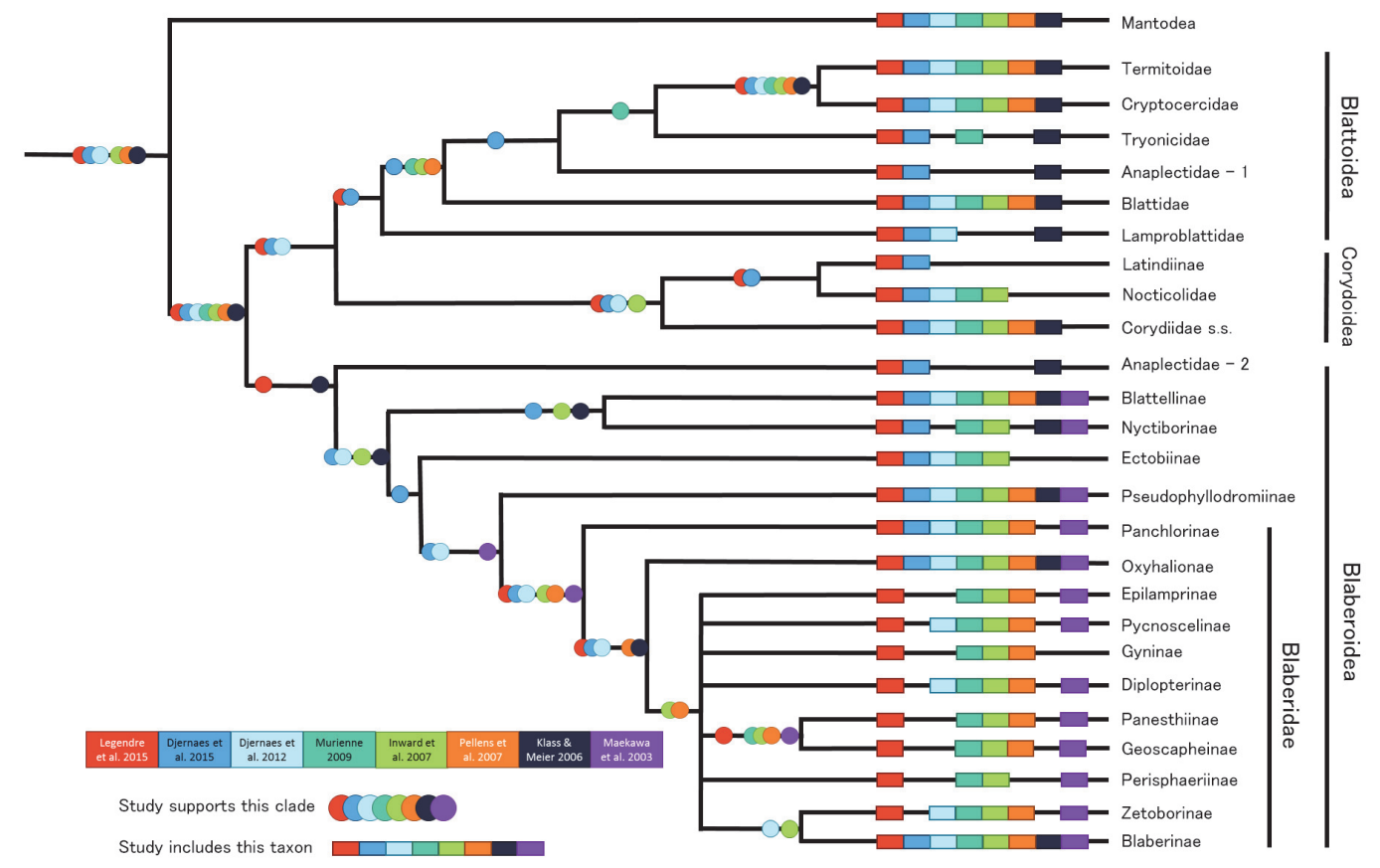

FIGURE 1. Cladogram of Blattodea phylogeny synthesized from eight previous studies (figure 2 in Maekawa et al., 2003; figure 4 in Klass and Meier, 2006; figure 1 in Inward et al., 2007; figure 3 in Pellens et al., 2007 ; figure 2 in Murienne, 2009; figure 2 in Djernæs et al., 2012; figure 3 in Djernæs et al., 2015; figures 4, 5, and 6 in Legendre et al., 2015). Support for a clade is represented by circles, each colored to indicate the studies in which that clade was recovered. Inward et al. (2007) and Pellens et al. (2007) do not report all support values for nodes on their trees so support from the topology of these studies may be over-represented here. The numbering next to Anaplectidae represents different possible positions of this group, or the potential that this group is polyphyletic. Legendre et al. (2015) supports Blattoidea and Blattoidea + Corydioidea but without Anaplectidae - 1, yet will still note their support for these clades with this one exception. Single terminals are shown for other taxa even though some may prove paraphyletic or polyphyletic with further study (e.g., Pseudophyllodromiinae and Epilamprinae). We did not find any reliably supported relationships within most of the Blaberidae, and thus its phylogeny is largely a polytomy. In some cases, a clade was recovered but the study had insufficient taxon sampling to support that clade (e.g., Maekawa et al., 2003 recovered Blattodea as monophyletic by necessity because it did not include Mantodea or other outgroup taxa). 


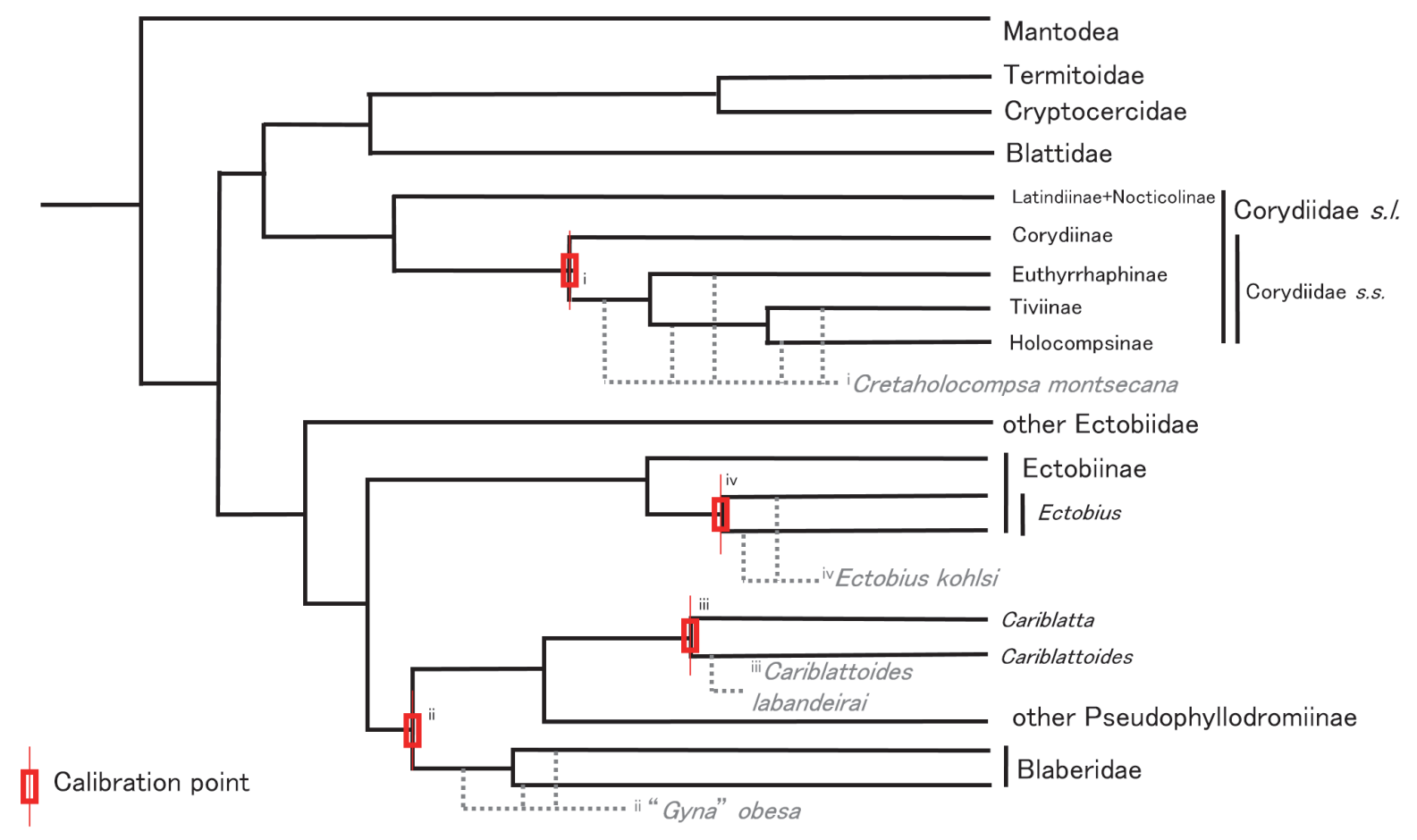

FIGURE 2. Simplified topology of Blattodea with fossil calibrations. Tree topology is simplified from Figure 1. Fossils are shown in grey with dashed lines to represent uncertain position within containing clade. Red symbol indicates the nodes each fossil calibrates with roman numerals indicating the fossil that corresponds to each node calibration. The minimum dates for each of the calibration points are: i - $125.45 \mathrm{Ma}$; ii - $52 \mathrm{Ma}$; ii - 48.14 Ma; iv - 48.14 Ma. Corydiidae s.s. consists of Holocompsinae, Tiviinae, and Euthyrrhaphinae. Corydiidae s.l. consists of Corydiidae s.S., Latindiinae and Nocticolinae. Note that no Ectobiinae other than Ectobius have been used in molecular phylogenetic studies to date.

support for clades in each of the studies listed above. We typically did not accept clades with bootstrap support under 0.6 or posterior probability support under 0.8. Inward et al. (2007) and Pellens et al. (2007) do not report all support values for nodes on their trees, so support from the topology of these studies may be over-represented. In the tree topology, we incorporated nodes recovered with these threshold support levels even if that node was collapsed in some other results (i.e., we erred towards more fully resolved results).

We took a highly conservative approach in choosing fossils, only accepting fossils with strong phylogenetic justification. This required that the fossils have multiple independent morphological features supporting their placement in a group, a standard of evidence in line with what is required for placement of extant taxa. Compared to past authors, we give less credence to certain wing and tegminal venation characters because they tend to have high levels of homoplasy and have been inadequately studied in the past (Rehn, 1951; see
Appendices 1 and 2). We interpret venation characters much more skeptically than the previous literature has done, and we disagree with the phylogenetic justification of certain fossils (e.g., Pseudoplecta krassilovi Vršanský and Anisyutkin, 2008; Periplaneta houlberti Piton, 1940; Paratropes fossilis Vršanský and Anisyutkin, 2008) as a result. Yet there are some wing and tegminal characters that are informative, particularly when used in combination. Tegmina and hind-wings are frequently the only cockroach body parts preserved in fossils, so interpreting these in a way that reflects true phylogenetic character distributions is important. We follow the terminology of both Rehn (1951) and Kukalova-Peck and Lawrence (2004) for the wing and tegminal venation.

We first tabulated all fossils of crown subfamilies in Blattodea from the online database Fossil Works (Alroy et al., 2016) (accessed: 4 - Nov 2015). Then we evaluated the phylogenetic justification for each fossil, beginning with the oldest and working forward in time. We primarily used Rehn 
(1951) as a resource for wing and tegminal morphology. We exhaustively mined Rehn's paper for data, tabulated its characters extensively (Appendix 1), and provide a brief review of this work in Appendix 2. We also noted many of the cases in which the paper is in error (Appendix 2) and so reevaluated statements in the text against the morphology observable in the illustrations, or other relevant primary taxonomic works. If phylogenetic placement of each fossil was justified, we then added repository information and appropriate age justification if it was available. This was in keeping with the best practices of fossil calibration (Parham et al., 2012). If the best practices could not be met, then the fossil was not considered as a calibration point. Each calibration provides a hard minimum bound for the estimated age of the node. The age justifications noted for each fossil are taken from the literature. In every case, when there was a range of ages given for the age of a geologic deposit, we utilize the age at the lower end of the range.

To reassess the holotype of "Gyna" obesa (Piton, 1940) (MNHN.F.R06689) we used the methods of Béthoux et al. (2016) to capture RTI images (still images with hemispherical lighting from 64 different angles; Appendix 3). The RTI images and regular photographs were taken on a Canon EOS 5D Mark III camera both with and without polarized light (unpolarized for RTI). All images were post-processed in GIMP (GIMP, 2016) and Mathematica 10 (Wolfram Research, 2012). Drawings were made both by hand using a camera lucida and digitally in GIMP and then synthesized to a single drawing (GIMP, 2016).

\section{CALIBRATIONS}

\section{Crown Corydiidae s.s.}

Calibrated node. This calibration corresponds to the crown Corydiidae Saussure, 1864, excluding the clade containing Latindiinae Handlirsch, 1925, and "Nocticolidae" Bolivar, 1892. We refer to this clade as the Corydiidae sensu stricto.

Species. Cretaholocompsa montsecana MartinezDelclos, 1993.

Specimen Number. LC-1704-IEI, the holotype, is deposited in the Fundació Pública Institut d'Estudis llerdencs en Lleida in Spain. This is a compression fossil showing tegmina, partial thorax (middle legs, pronotum), and head (Figure 3.1).

Phylogenetic justification. The venation of the tegmina are the primary justification for the placement of this fossil in Corydiidae (Martinez-Delclos,
1993). Tegmina of Corydiidae are not as distinctive as the hind wings (Rehn, 1951), however, this fossil has no hind wings to examine. Nonetheless, the tegmina do contain a number of distinctive features of the Holocompsinae. Synapomorphies of the tegmina shared by this fossil and the Holocompsinae are: lack of venation in apical portion, shortened radius $(R)$ with anterior branches, cubitus $(\mathrm{Cu}$; a.k.a. cubital-1 or $\mathrm{CuA}$ ) simple and incomplete, and basally or medially angulate plical furrow (a.k.a. cubital-2 or CuP) (Rehn, 1951). The simple subcosta (Sc) is also found in Holocompsinae, but is convergently present in other taxa as well. However, as discussed below, a liberal interpretation of these characters does not exclude this fossil from the Euthyrrhaphinae, another subfamily of Corydiidae. These two subfamilies form a clade that is the sister taxon to Corydiinae, and these three subfamilies together constitute the Corydiidae (excluding Latindiinae Handlirsch, 1925, and "Nocticolidae" Bolivar, 1892) (Djernæs et al. 2015; Legendre et al., 2015; Inward et al., 2007). Hence, we place this specimen as a crown member of Corydiidae s.s., but not within crown Holocompsinae.

Minimum Age. $125.45 \mathrm{Ma}$.

Age justification. The minimum age is based on the upper boundary of the Barremian. This species is found at the "La Pedrera Rúbies" and "La Cabrua" formations located in Montsec, Spain, west of the town of St. Maria De Meia. The holotype is from one of these two sites (the original description refers to the formation in which it is found and that this formation spans the distance between these two fossil sites). Martin-Closas and Lopez-Moron (1995) dated these formations to the Barremian Stage (125.45 Ma) as they lay within limestone bearing the charophyte Atopochara trivolvis triquetra Grambast, 1968 (Martinez-Delclos, 1990). The layer beneath bears benthic foraminifera of Berriasian age (Gomez et al., 2002), and the layer above it is categorized by rich fauna of orbitolinids, dated to the Late Barremian or Early Aptian age (Gomez et al., 2002), consistent with the Barremian estimate. Though some studies (e.g., Brenner et al., 1974) have given older age estimates for the charophyte bearing limestone strata yielding $C$. montsecana, but we accept the more recent, more conservative age.

Discussion. Vršanský and Ansorge (2001) and Vršanský (1999) also describe Corydiidae from around the same time period. However, Cretaholocompsa montsecana Martinez-Delclos, 1993 has a stronger phylogenetic justification (due to the similarity of the fossil tegmina to extant subfamilies) 


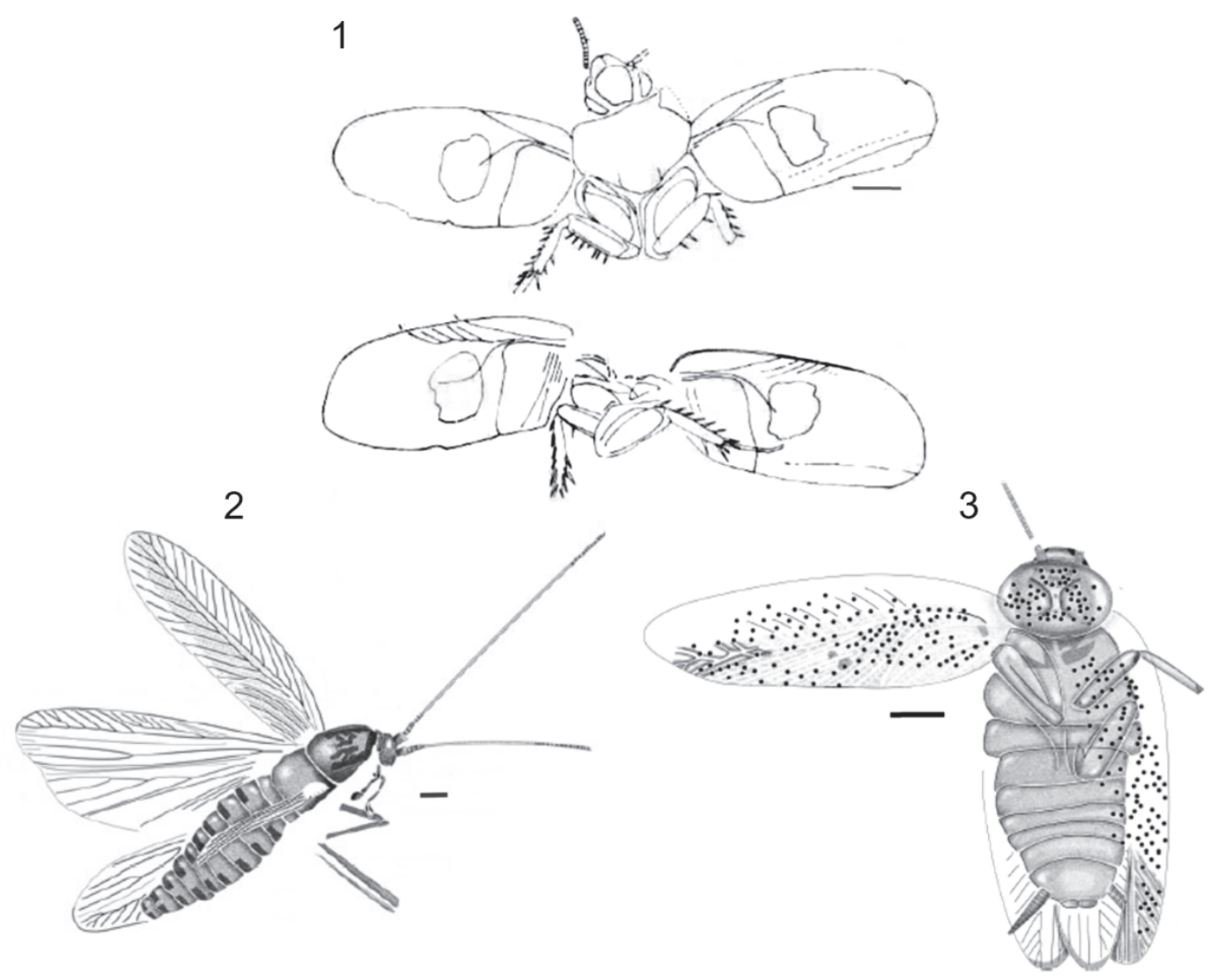

FIGURE 3. Illustrations of calibrating fossils. All illustrations reproduced with permission. Scale bars equal $1 \mathrm{~mm}$. 1, Cretaholocompsa montsecana Martinez-Delclos, 1993 (in Martinez-Delclos, 1993, figure 8). 2, Cariblattoides labandeirai Vršanský, Vidlička, Čiampor, Jr. and Marsh 2012 (in Vršanský et al., 2012, figure 12). 3, Ectobius kohlsi Vršanský, Vidlička, and Labandeira 2014 (in Vršanský et al., 2014, figure 3).

and the general gestalt of the habitus, which is very similar to extant Holocompsa.

Yet, the phylogenetic status of Cretaholocompsa Martinez-Delclos, 1993 in Holocompsinae can be questioned as well. First, the fossil has numerous anal veins (Martinez-Delclos, 1993), a trait not found in extant Holocompsinae. If Cretaholocompsa Martinez-Delclos, 1993, were to be placed in Holocompsinae it would require extending the morphological scope of the subfamily to include this character, giving it a broader taxonomic definition. Second, the multiple traits linking this fossil to Holocompsinae are likely related to the singular trait of having lost venation in the apical portion of the tegmina. As such, acceptance of this fossil on the grounds that it shares multiple independent traits with extant Holocompsinae may be premature. Euthyrrhapha Burmeister, 1838, the only genus in the subfamily Euthyrrhaphinae, has an almost complete reduction in venation in its teg- mina. In the case of Euthyrrhapha Burmeister, 1838, the venation is lost in accordance with a thickening of the tegmina. The plical furrow (a.k.a. CuP) vein is listed by Rehn (1951) as being sinuate in Euthyrrhaphinae and does have a slight angulation at approximately the basal third, which is similar to the angulation seen in this fossil. The spot in the tegmina is also shared between Euthyrrhaphinae and Holocompsinae. Murienne (2009) included these taxa in a molecular phylogeny, and both fell within Corydiidae but were bisected by Tivia Walker, 1869. For these reasons, we list this fossil as a calibration point of Corydiidae s.s. (i.e., Tiviinae + Holocompsinae + Euthyrrhaphinae + Corydiinae) and not Holocompsinae or Holocompsinae + Euthyrrhaphinae.

Although this is the oldest cockroach we report in this paper, it is not an appropriate fossil to calibrate the origin of Blattodea. Fossil termites used by a number of studies (e.g., $130 \mathrm{Ma}$ old 
Valditermes brennenae in Misof et al. (2014); 130 Ma old Valditermes, 130 Ma old Meiatermes, and $140 \mathrm{Ma}$ old Baissatermes in Ware et al. (2010); $140 \mathrm{Ma}$ old Mastotermes nepropadyom in Legendre et al. (2015)) are older than Cretaholocompsa montsecana.

\section{Stem Blaberidae}

Calibrated node. This node marks the divergence between Blaberidae Saussure, 1864, and its extant sister taxon (currently hypothesized to be Pseudophyllodromiinae).

Species. "Gyna" obesa (Piton, 1940)

\section{Gyna obesa Piton, 1940, fig. 11.}

Specimen number. MNHN.F.R06689 (Museum National D'Histoire Naturelle in Paris, France; specimen number 979 of the describing author), the holotype, is an impression fossil showing the dorsal body with the right tegmen extended (Figure 4).

Redescription. Adult male specimen fully macropterous with wings longer than body. Tegmina with parallel sides basally. CuP vein (plical furrow) arcuate overall but sharply rounded at basal origin. CuP with one visible ramus extending distally. At least 12 anal veins distinct but more are present; anterior veins convexly arcuate and posterior veins concavely arcuate. Punctuations resulting from intercalaries present and most abundant on posterior-basal half. Cerci stout. Subgenital plate asymmetrical with right margin concave (as in Africalolampra Roth, 1995, Gyninae, or Panchlorinae for example). Measurements: body $25.9 \mathrm{~mm}$ (anterior margin of pronotum to posterior-medial edge of abdomen), pronotum $7 \mathrm{~mm}$ long (or 8.5 if bearing posterior-medial extension) and $\sim 9.5 \mathrm{~mm}$ wide, cercus (left) $1 \mathrm{~mm}$ long, wings $\sim 26 \mathrm{~mm}$ long, tegmen (left) $>23 \mathrm{~mm}$, anal area of tegmen $\sim 12$ $\mathrm{mm}$ long.

Phylogenetic justification. The characters seen in the fossil do not support a generic or subfamilial placement but they do indicate that the species is a member of Blaberidae. We base this primarily on the stout cerci, shape of the tegmina, shape of CuP (plical furrow), shape of the pronotum, shape of the posterior-most abdominal segment and overall body size. First, the visibly stout cerci are a synapomorphy of Blaberidae and are not seen in Ectobiidae, although they may be confused with convergently evolved stoutness of the cerci in some genera of Blattidae and Corydiidae. Second, the tegmina have approximately parallel edges, which is uncommon in Corydiidae but common in Blaberidae, Blattidae and Ectobiidae (Rehn, 1951).
The anal area, delimited by the CuP vein, is elongated. This elongation is common in Blaberidae, Blattidae, and Ectobiidae but not seen in most Corydiidae, whose CuP typically have a sharper angulation. One trait observed in the fossil that is frequently seen in Corydiidae is the branching of CuP. However, this feature also occurs in other groups, and shows substantial intraspecific variation as well (e.g., observed in approximately one third of individuals of some Blaberidae species; Olivier Béthoux, personal commun., 2017). Piton's original description showed the pronotum elongated postero-medially. This is rarely found outside of the Blaberidae and would be strong evidence for its placement in this family, however, our reassessment shows that the shape of the pronotum is not entirely clear. We present high resolution photos of the prothorax with hemispherical lighting in the form of an RTI image file (Appendix 3 ) but still cannot precisely discern the shape of the pronotum. The more posterior candidate for the edge of the pronotum could be sculpturing of the middle thoracic segment. One character Piton failed to assess is the shape of the terminal segment. We believe that the specimen is preserved lying on its dorsal side, due to at least one visible leg and lack of discernible tegminal venation on the left side of the stone. If this is the case then the terminal abdominal segment is the subgenital plate, which appears to be asymmetrical, with the right side bearing a concave margin. This is a subgenital plate shape typical of Epilamprinae, Panchlorinae and Gyninae. Considering all these characters together along with the robust proportions, and body size of $25.6 \mathrm{~mm}$, we feel confident that this fossil is placed within the Blaberidae, although its subfamilial assignment is uncertain. This fossil provides a minimum age for the split between Blaberidae and its sister taxon. Djernæs et al. (2012, 2015), Maekawa et al. (2003), and Grandcolas (1996) all place Pseudophyllodromiinae as sister to Blaberidae Saussure, 1864 but other recent assessments dispute this (Figure 1 and unpublished data), so we do not set a relationship here.

Minimum Age. $52 \mathrm{Ma}$.

Age justification. Stroiński and Szwedo (2012) reviewed the geological setting for this fossil deposit (Menat, France). K/Ar isotope analysis (Vincent et al., 1977) dated the formations around Menat to an average of $56 \mathrm{Ma}$, but the minimum age measurement given is $54+/-2 \mathrm{Ma}$ (Vincent et al. 1977). Biostratigraphic evidence from pollen and mammals, and macrofloral analysis (Kedves, 1982; Kedves and Russell, 1982; Nel, 2008; Wap- 

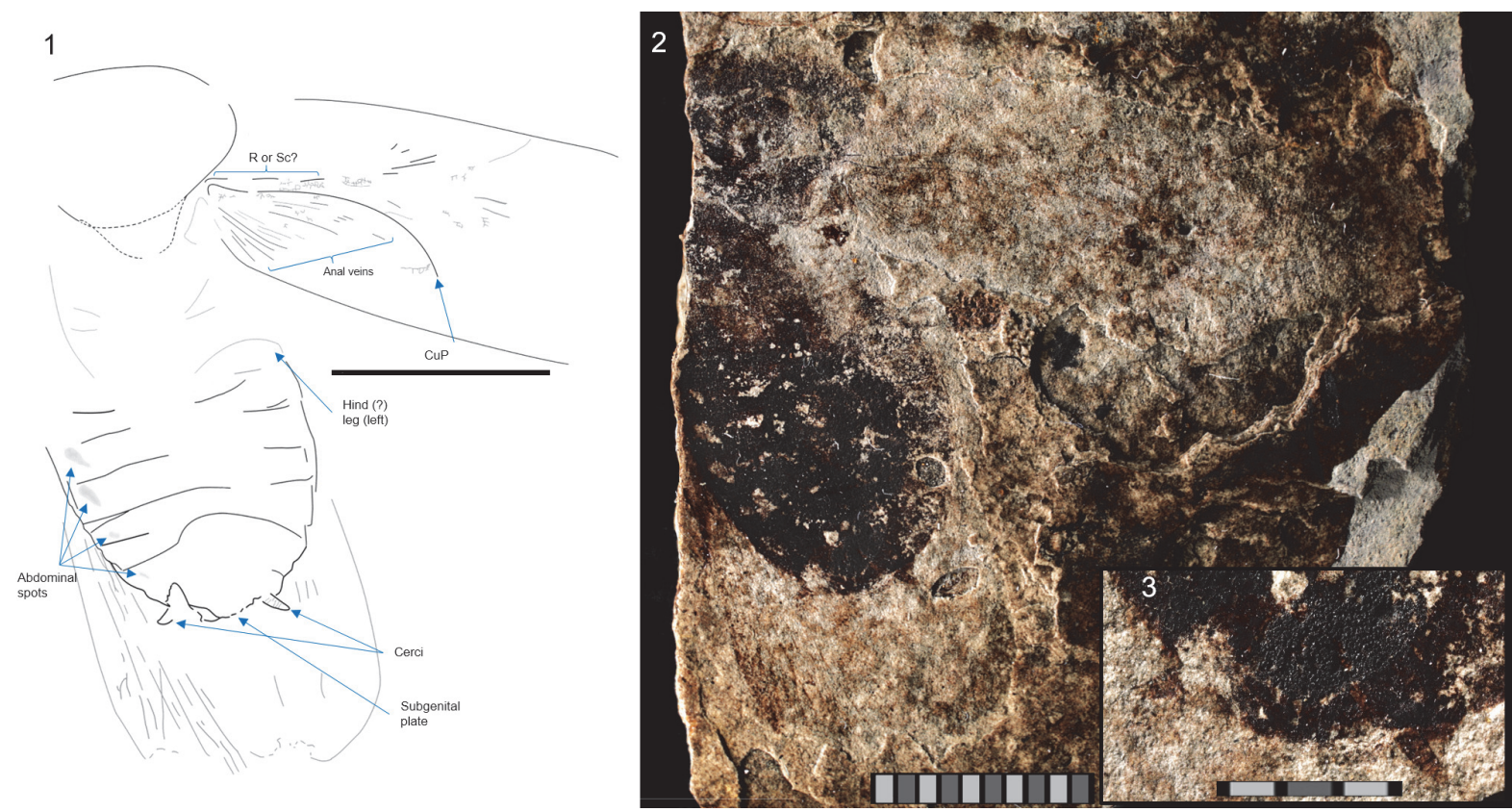

FIGURE 4. "Gyna" obesa (Piton, 1940) with ventral perspective. 1, Illustration of holotype. Hashed line on pronotum denotes two possible paths delimiting the posterior margin of the pronotum. Broken lines elsewhere denote damage or incomplete preservation. Scale bar equals $10 \mathrm{~mm}$. 2, Photo of holotype MNHN.F.R06689. Photo is a composite of two images taken with polarized lighting at different angles. Scale $10 \mathrm{~mm}$ total. 3, Higher magnification of posterior end showing stout, segmented cerci and details of abdominal termination. Scale $3 \mathrm{~mm}$ total.

pler et al., 2009) indicate older ages up to $61 \mathrm{Ma}$. We use the lower end of this age range as a hard minimum date for the calibration.

Discussion. Upon reassessment (Figure 4) we find that many of the characters reported by Piton (1940), in the text description or in his figure, greatly over-interpret the details present in the fossil. Piton (1940) reported on the following tegminal characters, and we add their systematic distribution: subcostal (Sc) present and simple (also present in Corydiidae, Blattidae, Blattellinae, Ectobiinae, and Pseudophyllodromiinae); R1 (first anterior branch of the radial vein) present and simple (also present in Pseudophyllodromiinae); cubitus (Cu; a.k.a. CuA) with five or more branches and free from media (also found in Blattellinae, Nyctiborinae and Blattidae), cubitus (CuA) arcuate (found in Blattidae, Corydiidae, Ectobiinae, Blattellinae and Morphna) and terminating in the posterior margin (also present in Corydiidae, Blattellinae, Blattidae, Ectobiinae and Anaplectinae). When reexamining the fossil we see that most of these characters are not discernable at all. Although the plical furrow (CuP) is mostly intact, the vein fragments corresponding to the $\mathrm{M}$ and $\mathrm{CuA}$ vein are not differentiable. There are clear traces of a strong vein anterior to the CuP, but it is unclear if this is the subcosta or the radius. The two may not be discernable though because many Blaberidae have the radius stalked on the subcosta (Rehn, 1951; Appendix 1).

Piton (1940) suggests the identification of this fossil as Gyna Brunner von Wattenwyl, 1865, based on tegminal venation, and pronotal shape. The pronotal shape could be very similar to that of Gyna Brunner von Wattenwyl, 1865, but this shape is present in other Blaberidae as well. There are no other characters observed in this fossil that support a placement in Gyninae or another subfamily. There are also no clear characters on which to establish a new genus. Thus, we remove this species from the genus Gyna and leave it as an unplaced blaberid.

Another fossil, Morphna paleo Vršanský, Vidlička, Barna, Bugdaeva, and Markevich, 2013, is dated at $~ 9-15$ million years older than "Gyna" obesa. However, we support the use of "Gyna" obesa as the calibration fossil over M. paleo based on their phylogenetic justifications. $M$. paleo was described entirely based on a partial forewing. In the description, the main characters emphasized are cross veins in the cubitus (Cu; a.k.a. $\mathrm{CuA}$ ) and media (M) (Vršanský et al., 2013) but this is found in both the Blaberidae and Pseudophyllodromiinae 
(Rehn, 1951). There are other characters that may indicate that this fossil is in the Blaberidae, and more specifically Epilamprinae, but these cannot be supported by independent evidence from the body morphology, as in the fossil described here. Thus, we do not claim that the purported placement of M. paleo is incorrect, but simply that it cannot be strongly verified based on the evidence we have so far.

\section{Cariblattoides + Cariblatta}

Calibrated node. This node dates the divergence between Cariblattoides Rehn and Hebard, 1927 and its extant sister taxon, presumed to be Cariblatta Hebard, 1916.

Species. Cariblattoides labandeirai Vršanský, Vidlička, Čiampor Jr. and Marsh 2012.

Specimen number. USNM 542284 (Smithsonian National Museum of Natural History in Washington DC, USA). This complete body specimen, the holotype of the species, is an impression fossil (Figure 3.2).

Phylogenetic justification. The authors of this species justify its taxonomic placement with 13 characters of the hindwing, forewing, coloration, palps, and body shape (Vršanský et al., 2011). Specifically, important synapomorphies linking $C$. labandeirai Vršanský, Vidlička, Čiampor Jr., and Marsh, 2012, with other Cariblattoides are: terminal palpomeres short and cup-like, tegmina highly elongated, branched cubital vein (Cu; a.k.a. CuA) in tegmina and hindwing radial veins ( $R$ or $R S$ ) mostly simple. Vršanský et al. (2011)'s phylogeny places C. labandeirai as sister to the extant Cariblattoides piraiensis Rocha e Silva, 1955, which is endemic to Brazil.

Minimum age. 48.14 Ma .

Age justification. The holotype is given the locality "Denson site", an outcrop of the Parachute Creek Member of the Green River Formation that is located in the Piceance Creek Basin of Colorado (Wappler et al., 2015). This upper and lower age bound for this layer are $51.24(+/-0.52) \mathrm{Ma}$ and 48.37 (+/- 0.23) Ma respectively. The lower age limit is based on single crystal laser incremental ${ }^{40} \mathrm{Ar} /{ }^{39} \mathrm{Ar}$ dating of volcanic phenocrysts (Smith et al., 2008).

Discussion. This fossil is currently the oldest described fossil in the Pseudophyllodromiinae (Alroy et al., 2016). The nearly complete holotype allows numerous morphological characters to be identified supporting the phylogenetic placement. Although the original phylogeny only includes a single outgroup (consensus morphology of Cari- blatta Hebard, 1916) (Vršanský et al., 2011), which does not allow for a rigorous test of the monophyly of the genus, the common practice of modern cockroach taxonomy remains to use morphological diagnostic traits and synapomorphies. The large number of synapomorphies shared with extant Cariblattoides indicates the fossil species is more closely related to the extant species comprising this genus than any other extant taxa and probably the crown member of the genus. However, given the rooting issues with the available phylogeny we conservatively apply the calibration to the node indicating the divergence of Cariblattoides from Cariblatta.

\section{Crown Ectobius}

Calibrated node. This node represents the basal divergence within Ectobius Stephens, 1835.

Species. Ectobius kohlsi Vršanský, Vidlička, and Labandeira, 2014 (in Vršanský et al., 2014).

Specimen number. USNM 53274 (Smithsonian National Museum of Natural History in Washington, D.C., USA) is a whole body impression fossil of a female (Figure 3.3).

Phylogenetic justification. Vršanský et al. (2014) place this fossil as a member of either the Krasussianus or Sylvestris species group. This is supported by a number of morphological characters. The separate media and radial vein is shared with extant E. ticinus Bohn, 2004 (Sylvestris sp. group). The forewing coloration (maculae patterns) is identical to that of E. brunneri Seoane, 1879 (Sylvestris sp. group). Presence of pronotal punctae is seen in E. brunneri (Sylvestris sp. group) and E. panzeri Stephens, 1835 (Capraiellus group). The presence of two symmetrical arcuate pronotal ridges is shared with E. sylvestris (Poda, 1761), E. kraussianus Ramme, 1923 (Krasussianus sp. group), E. lagrecai Failla and Messina, 1981, and E. aetnaeus Ramme, 1927 (Sylvestris sp. group). All these features support the association of this species with extant subgenus Ectobius (Ectobius) Stephens, 1835, as opposed to the subgenus Ectobius (Ectobiola) Uvarov, 1940, which has dark spots on the tegmina and is lacking punctae. Vršanský et al. (2014) suggested that Ectobius (Ectobiola) may not be sister to Ectobius (Ectobius) but is a member of the Lapponicus species group of Ectobius. Vršanský et al. (2014) also differentiate this fossil from other Ectobius species groups in that they are lacking the pronotal ridges, have different coloration on the pronotum or tegmina, have different punctae patterns, have different shape of cerci, and have different gland morphology. Because the 
sister taxon to the Krasussianus and Sylvestris species groups of Ectobius are not known, this fossil should be used to calibrate the basal split in Ectobius.

Minimum age. 48.14 Ma.

Age justification. This fossil is from the Parachute Creek member of the Green River Formation. The upper and lower age bound for this layer are 51.24 (+/- 0.52) Ma and 48.37 (+/- 0.23) Ma, respectively. The lower age limit is based on single crystal laser incremental ${ }^{40} \mathrm{Ar} / 39 \mathrm{Ar}$ dating of volcanic phenocrysts (Smith et al., 2008).

Discussion. Ectobius Stephens, 1835, fossils are known from throughout the Eocene and Oligocene in both rock and amber (Germar and Berendt, 1856; Statz, 1939; Vršanský et al., 2014). Other fossil Ectobiinae reported by Piton (1940) date to 55.8 Ma. However, the phylogenetic justifications for Piton's impression fossils are severely flawed. Their poor preservation and the limited morphological description makes it impossible for us to confirm their placement within Ectobiinae. Thus, $E$. kohlsi Vršanský, Vidlička and Labandeira, 2014 (in Vršanský et al., 2014) is considered the oldest securely identified fossil representative of Ectobiinae.

\section{DISCUSSION}

\section{Calibrations for Basal Dictyoptera}

Cockroach-like fossils, typically termed "roachoids", become abundant around 300 Ma. These Carboniferous age fossils preserve some of the highly conserved external morphology seen in extant cockroaches but also possess an external ovipositor, a trait not found in any extant dictyopterans. It has been proposed that these fossils could be ancestral polyneopterans (Kjer et al., 2015), on the stem of Dictyoptera (Tong et al., 2015), or even within Blattodea (Vršanský et al., 2009).

Part of this uncertainty stems from the fact that the taxonomic identity of many described fossils is based heavily on the limited characters of wing or tegminal morphology. Since it has been shown here and elsewhere (Ross, 2012) that wing venation characters are highly unreliable for phylogenetic justifications within Blattodea, we are not confident in many relationships largely derived from these characters, particularly for fossils that predate the earliest crown Blattodea fossils by 160 Ma. While the precise phylogenetic placement of the roachoids remains unresolved, we advocate abandoning the idea that they represent crown Blattodea or crown Dictyoptera. In particular, the presence of an external ovipositor makes these scenarios unparsimonious as this character is not present in any extant Mantodea or Blattodea.

After omitting the possibility that roachoids represent crown Dictyoptera, they could plausibly be stem Dictyoptera, crown Polyneoptera, or stem Polyneoptera. Our ability to use roachoid fossils as calibration points for nodes delimiting crown groups on the insect tree is limited by both: (1) lack of strong morphological features unambiguously associating roachoids with extant lineages and (2) lack of a resolved phylogeny of Polyneoptera. Even if we are certain of (1) then we could only use such a fossil to calibrate the base of Polyneoptera, since relationships in Polyneoptera have never been reliably recovered, and the extant sister group to Dictyoptera is not known. Regardless of how likely it seems that roachoids are stem dictyopterans, placing them in an objective and systematic way is problematic at this time. In one extreme case, an extinct insect lineage once hypothesized to represent a stem dictyopteran (Anthracoptilidae) could instead be placed in Paraneoptera or even Holometabola (Guan et al., 2015). Placing these fossils in Polyneoptera is difficult because of the morphological disparity of these groups. Very few morphological synapomorphies of Polyneoptera are known, and those that are known (e.g., fine structures of the wing base; Yoshizawa, 2011) do not preserve well or are difficult to discern in impression fossils (e.g., Béthoux et al., 2011).

\section{Calibrations for Crown Blattodea}

There are many older specimens of purported Blattodea that we do not accept as calibration points (Appendix 4). We are not able to effectively place these taxa within the crown Blattodea as opposed to stem dictyopteran or stem blattodean groups. Therefore, we cannot consider their validity for use as a calibration. Among these taxa are: Mesoblattinidae Handlirsch, 1906, Liberiblattinidae Vršanský, 2002, Caloblattinidae Vršanský, 2000, Blattulidae Vishnyakova, 1982, Ponopterixidae Nel, Prokop and Kirejtshuk, 2014, Phyloblattidae Schneider, 1983, Socialidae Vršanský, 2010, Manipulatoridae Vršanský and Bechly, 2015, Eadiidae Vršanský, 2009, Mutoviidae Vršanský and Aristov, 2012, Skokidae Vršanský, 2007, and Fuziidae Vršanský, Liang and Ren, 2009.

\section{Calibrations for Crown Blaberoidea}

There are many described species of Piniblattella Vršanský, 1997, that would qualify as some of 
the oldest Blattodea or at least oldest Blaberoidea and Blattellinae. However, the placement of this genus in Blattellinae is not justified. All of the characters used to justify this placement are wing and tegminal characters that are polymorphic within the Blattellinae or distributed polyphyletically within all Blattodea (Appendix 1; Rehn, 1951). Furthermore, the females have a valvate subgenital plate (Vršanský, 1997), a character that is not known among extant Blattellinae and only seen in the Blattoidea (McKittrick, 1964) and Anaplectidae (whose phylogenetic position is under great scrutiny; see Djernæs et al., 2015). Even if we accept that the wings do assign this genus to Blattellinae, the female subgenital plate should discount this.

Grimaldi and Engel (2005) show an Early Cretaceous impression fossil, which appears to be a representative of Blaberoidea, as it is preserved holding an ootheca that is rotated $90^{\circ}$ (figure 7.72 in Grimaldi and Engel, 2005). If given a full systematic treatment, this fossil could be the oldest fossil Blaberoidea, or maybe Blattellinae. It is possible though that the rotation is a product of the early fossil preservation stages.

Shelford (1910) described amber fossils of 13 Blattellinae (Ischnoptera Burmeister, 1838, and Blattella (syn. Phyllodromia) Caudell, 1903) and one Nyctiborinae from the Priabonian Stage (Baltic Amber). The amber Ischnoptera Burmeister, 1838, have some of the diagnostic characters for the genus (front leg spination type B: Roth, 2002; sulci in pronotum: Roth, 2002) but both these characters are homoplastic within Blattodea. A genital hook is visible in some of these specimens but its position (left or right) is not noted. These specimens should be redescribed using modern techniques and taxonomic knowledge.

The Nyctibora Burmeister, 1838, fossil described by Shelford (1910) may be more convincing than the Ischnoptera Burmeister, 1838, given its apparent possession of microscopic silky hairs, a trait that is not often seen in other extant cockroaches. Yet, Shelford (1910) himself admits that his placement of this specimen should be under considerable doubt and presented highly subjective evidence for its identity. Given that this individual is a juvenile, and that extant Nyctiborinae are known only from the Neotropical region, we do not feel it is appropriate to utilize this fossil as a conservative lower limit for the age of this subfamily.

A much older Nyctiborinae is described by Vršanský and Anisyutkin (2008). However, this description is based solely on an isolated right teg- men. The characters in the tegmen do not justify its placement, e.g., the authors list many as plesiomorphies and further note that many characters are present due to mutations or physical abnormalities.

Nehevblattella grofitica Vršanský, 2004, is another purported Ectobiidae that would be the oldest fossil in the Blaberoidea if its position was accepted (Vršanský, 2004). However, this is described based on tegminal characters only. Nearly all the characters given for its position in Ectobiidae (cubitus (CuA) reduced, plical furrow (CuP) $1 / 2$ tegminal length, tegmina wide; Vršanský, 2004) are distributed polyphyletically throughout Blattodea (Appendix 1; Rehn, 1951).

Vršanský et al. (2016) described three species of Diploptera from the Green River, Colorado fossil deposits. However, the phylogenetic placement of these fossils in this genus is not justified. The diagnostic features for the genus are stated in the paper as: beetle-like, female brood sac present, tegmina with cup-like structures, hindwing elongated, and double pleated. Out of all of these features, only the beetle-like form and cup-like structures in the forewing can be seen in the fossils. The authors claim that the brood sac is unique to the viviparious Diplopterinae and visible in their fossils. Based on their figures, our determination is that there is little if any evidence of a visible brood sac. Additionally, there are many genera of cockroaches that have cup-like structures, or pits covering the tegmina (e.g., Lucihormetica, Hemiblabera), and these taxa can frequently be beetle-like (e.g., Colapteroblatta, Eustegasta, Calhypnorna).

Che et al. (2017) use Epilampra sp. Pongrácz, 1935, Pycnoscelus gardneri Cockerell, 1920, and Zetobora brunneri Scudder, 1890, as calibration bounds for their $\mathrm{COI}$ gene tree. All of these fossils were described before paleoentomologists had any modern understanding of cockroach systematics or morphology, so the descriptions cannot be relied upon. Pongracz (1935) described Epilampra sp. based on a single incomplete tegmina with no diagnostic characters. Cockerell (1920) described $P$. gardneri based on only an incomplete tegmen, and by his own admission this did not provide any characters of generic value. In our assessment this fossil cannot be reliably placed in a family based on the characters given in its description: Sc branched, radial branches oblique, Sc parallel with $\mathrm{R} 1, \mathrm{R}$ secondarily branched, $\mathrm{M}$ and $\mathrm{Cu}$ with 9 branches. The original description of $Z$. brunneri is very poor, and we believe does not give compelling evidence for its placement in Blaberidae. Scudder 
(1890) gives no evidence for its placement, and his illustration of the fossil does not provide any diagnostic characters.

\section{Calibrations for Crown Blattoidea}

Šmídová and Lei (2017) and Sendi and Azar (2017) describe species of the genus Balatronis Šmídová and Lei, 2017, of the family Blattidae from Lebanese amber. However, Balatronis libanensis Sendi and Azar, 2017, is likely in a different family due to the presence of a central ocellus (not seen in any extant cockroaches). Balatronis cretacea Šmídová and Lei, 2017, the type species, is only supported in the family Blattidae by its similar coloration to the extant genus Neostylopyga Shelford, 1911. Šmídová and Lei (2017) admits that none of the characters reported for this species, other than the coloration, is indicative of Neostylopyga, Blattinae, or Blattidae. For these reasons and others (small body size may be indicative of another taxonomic assignment, slightly similar color patterns are seen in other Blattidae and some Pseudophyllodromiinae) we consider the evidence placing this species in the Blattinae too weakly justified for use as a fossil calibration.

Another fossil purported to represent one of the oldest records of Blattidae is placed in the extant genus Methana Stål, 1877 (Jell and Duncan, 1986). However, its phylogenetic justification is severely lacking (the authors only compared it to two very distantly related extant taxa) and cannot be evaluated thoroughly. Piton (1940) also describes some purported Blattidae (Prostylopyga gigantia, Periplaneta houlberti, Eoplaneta desforesti, and Zeunera spp.) but these are not phylogenetically justified due to the use of poor wing and tegminal venation characters. Two $40 \mathrm{Ma}$ old Periplaneta Burmeister, 1838, were described by Meunier (1921). However, the characters given for their phylogenetic justification are common to multiple families of cockroaches, including many Blaberoidea (e.g., branched subcosta, radial vein with multiple rami, numerous anal veins, some bifurcated anal veins).

A 33.9 Ma old Blattinae, Periplaneta succinica, was described by Shelford (1910). This may be the oldest valid fossil Blattidae and Blattinae. The phylogenetic justification for this fossil appears robust, however the specimen cannot currently be located in a museum. The collection it is a part of (Klebs collection) is mostly deposited in the Gottingen Museum at Koenigsberg-University. However, this collection was partially destroyed in World War II and the specimens currently in Gottingen
Museum collection do not have their original accession numbers (Alexander Gehler, pers. comm.). If Shelford's specimen can be found, this could be used as a fossil for date calibration. It should be noted though, that other "amber" fossils described by Shelford (1911) have later been found to be copal (Grimaldi et al., 1995).

\section{Other Calibrations}

Holocompsa nigra Gorokhov and Anisyutkin, 2007 (in Gorokhov, 2007) is a strongly justified fossil (accession number 371428 at the Smithsonian National Museum of Natural History in Washington, D.C., USA) from Dominican amber (26-15 Ma based on spectroscopal analysis (Brody et al., 2001)). The pronotal shape, tegminal venation (reduced apical venation, angulate plical furrow, and coriaceous basally), hindwing venation (presence of pterostigma formed by radius or radius and medial veins), and body hairs all support this fossil's placement as Holocompsa Burmeister, 1838 (Gorokhov, 2007). Despite the strength of this fossil it cannot currently be used as a calibration point. Holocompsinae is currently a monogeneric subfamily (however, see Princis, 1962 and Bonfils, 1987 who placed Hypercompsa Saussure, 1864 in the Holocompsinae) whose sister taxon is unknown (Tiviinae in Legendre et al., 2015 and Murienne, 2009; Tiviinae + Euthyrrhaphinae in Djernæs et al., 2015). Holocompsa is globally distributed with two old world species, seven new world and one circumtropical. In the event that Holocompsinae is split into multiple genera (by inclusion of Hypercompsa, splitting of Holocompsa geographically, or discovery of a new lineage) this fossil could calibrate the Holocompsa + "sister taxon" clade. However, this fossil should not be used to calibrate Holocompsinae since it is very possible that Cretaholocompsa is a Holocompsinae and this fossil is much older than Holocompsa nigra.

Vršanský and Anisyutkin described one purported Anaplectidae (Pseudoplecta krassilovi) from Israel (Anisyutkin et al., 2008). This description was based entirely on the tegmina, which were the only preserved parts in this impression fossil. Most of the characters used to justify this fossil's placement are found in a variety of extant cockroach groups (i.e., branched and sinuate subcosta, elongated tegmina, reduced venation). Furthermore, the authors themselves seem to be uncertain of its taxonomic designation, as they compared it to the distantly related Anaplectidae (Anaplecta Burmeis- 
ter, 1838) and Pseudophyllodromiinae (Prosoplecta Saussure, 1864).

Gutierrez and Perez-Gelabert (2000) presented amber fossils of species from 6 extant genera (Anaplecta Burmeister, 1838, Holocompsa Burmeister, 1838, Cariblatta Hebard, 1916, Euthlastoblatta Hebard, 1917, Plectoptera Saussure, 1864 and Pseudosymploce Rehn and Hebard, 1927). These could potentially be used to calibrate some shallow clades. Gutierrez and PerezGelabert (2000) do not provide a phylogenetic justification with their identifications so we cannot assess their fossils.

\section{CONCLUSIONS}

Only two previous studies (Legendre et al., 2015; Che et al., 2017) have used fossils within the scope of this paper as calibration points. Legendre et al. (2015) used four calibration points within Blattodea and Che et al. (2017) used five. We discuss each of these here and only accept one, Cretaholocompsa montsecana Martinez-Delclos, as a valid calibration point. Six others (Piniblattella vitimica (Vishniakova, 1964), Piniblattella sharingolensis Vršanský, 2005, Morphna paleo Vršanský et al., 2013, Epilampra sp. Pongrácz, 1935, Pycnoscelus gardneri Cockerell, 1920, and Zetobora brunneri Scudder, 1890) we reject on the grounds of insufficient phylogenetic justification. To reiterate from above: Piniblattella has characters conflicting with its placement in Blattellinae and even Ectobiidae; Morphna paleo Vršanský et al., 2013 has weaker evidence supporting its placement than "Gyna" obesa Piton, 1940, which is only 9-15 million years younger; Epilampra sp. Pongrácz, 1935, and Pycnoscelus gardneri Cockerell, 1920, were described entirely based on unreliable tegminal variation; and Zetobora brunneri Scudder, 1876, was not given any justification for its placement in Blaberidae. Holocompsa nigra Gorokhov and Anisyutkin, 2007 (in Gorokhov, 2007) we do not reject but simply find the current classifications insufficient to utilize this fossil properly.

Future studies should use the fossils we have provided here for calibrating date extrapolations on their molecular phylogenies and avoid the ones we have criticized, unless further evidence is presented for them. Particularly, future time-calibrated phylogenetic studies should use the fossils we note here if they include Corydiidae s.s., Blaberidae, Cariblattoides Rehn and Hebard, 1927, or Ectobius Stephens, 1835.

Most importantly, more rigorous fossil descriptions are needed. It is clear that the morphology of fossil cockroaches is hard to interpret because wings and tegmina provide such unreliable characters. We can counteract this by (1) describing and cataloging the wing morphology of more extant taxa and (2) utilizing more amber fossils, which could provide more morphological characters.

\section{ACKNOWLEDGMENTS}

The authors would like to acknowledge the service of the two reviewers of this manuscript, as well as the handling editor. Thank you to J. Ware (JW) and K. Klass advising the authors on aspects of the manuscript and to JW for providing lab space. We extend gratitude to O. Béthoux, who assisted with obtaining, and photographing "Gyna" obesa. He also gave advice on illustrating it and interpreting its morphology. Thank you to $S$. Toussaint who assisted with RTI. Appreciation to A. Gehler (Gottingen Museum at Koenigsberg-University) for providing information about the Klebs collection. Thank you to the publishers for allowing reproduction of their figures (Springer, Oxford University Press, and John Wiley and Sons). The US National Science Foundation (award number: 1608559) and Rutgers University provided funding for this research.

Author contributions: DE wrote the paper, evaluated the fossils, reviewed Rehn (1951), compiled the Appendix material, and constructed the figures. MD helped construct Figure 1 and provided comments on the paper. MKK designed the research plan, wrote the age justifications, edited the text and figures, and acted in an advisory role.

\section{REFERENCES}

Alroy, J., Marshall, C., Behrensmeyer, K., Miller, A., and Sepkoski, J. 2016. accessed December 2015. FossilWorks: Paleobiology Database.

http://fossilworks.org/

Anisyutkin, L.N. 2008. Paraeuthyrrhapha groehni gen. et sp. nov., a new genus of the family Polyphagidae (Dictyoptera) from Baltic amber and its phylogenetical position. Alavesia, 2:77-85.

Anisyutkin, L.N. 2014. On cockroaches of the subfamily Epilamprinae (Dictyoptera: Blaberidae) from South India and Sri Lanka, with descriptions of new taxa. Zootaxa, 3847:301-332.

doi:10.11646/zootaxa.3847.3.1

Anisyutkin, L.N., Rasnitsyn, A.P., and Vršanský, P. 2008. Part II: Insects in the fossil mangrove from South Negev, Israel. Cockroaches and Mantises, p. 8-29. In Krassilov, V. and Rasnitsyn, A.P. (eds.), Plant Arthopod Interactions in the Early Angiosperm History. Pensoft Publishers and BRILL, Sofia-Moscow, Russia and Leiden-Boston, USA. 
Beccaloni, G. and Eggleton, P. 2013. Order: Blattodea. Zootaxa, 3703: 46. doi:10.11646/zootaxa.3703.1.10

Béthoux, O., Llamosi, A., and Toussaint, S. 2016. Reinvestigation of Protelytron permianum (Insecta; Early Permian; USA) as an example for applying reflectance transformation imaging to insect imprint fossils. Fossil Record, 20:1-7. doi:10.5194/fr-20-1-2016

Béthoux, O. and Wieland, F. 2009. Evidence for Carboniferous origin of the order Mantodea (Insecta: Dictyoptera) gained from forewing morphology. Zoological Journal of the Linnean Society, 156:79113.

Béthoux, O., Schneider, J.W., and Klass, K.D. 2011. Redescription of the holotype of Phyloblatta gaudryi (Agnus, 1903) (Pennsylvanian; Commentry, France), an exceptionally well preserved stem-dictyopteran. Geodiversitas, 33:625-635. doi:10.5252/g2011n4a4

Bohn, H. 2004. The Blattoptera fauna of Switzerland and the adjacent regions of France, Italy and Austria. I. The species of the sylvestris-group of Ectobius (Blattellidae, Ectobiinae). Spixiana, 27(3): 253-285.

Bolívar, I. 1892. Étude sur les arthropodes cavernicoles de l'île de Luzon. In Raffray, A., Bolívar I., and Simon E. (eds.), Orthoptères. Annales de la Société Entomologique de France, 61:29-34.

Bonfils, J. 1987. Les blattes (Dictyoptera: Blattaria) du Venezuela. Fauna hipogea y hemiedafica de Venezuela y de otros paises de America del sur. Editura Academiei Republicii Socialists, 1:157-164.

Brenner, P., Geldmacher, W., and Schroeder, R. 1974. Ostracoden und alter der Plattenkalke von Rubies (Sierra del Monsech, Prov. Lerida, NE-Spanien). Neues Jahrbuch fur Geologie und Palaontologie, Monatshefte, 513-525.

Brody, R.H., Edwards, H.G.M., and Pollard, A.M. 2001. A study of amber and copal samples using FT-Raman spectroscopy. Spectrochimica Acta Part A: Molecular and Biomolecular Spectroscopy, 57:1325-1338.

Brunner von Wattenwyl, C. 1865. Nouveau Système Des Blattaires. La societe I.R. de Zoologie et de Botanique, Vienna.

Burmeister, H. 1838. Handbuch der Entomologie. Berlin, Germany. doi:10.5962/bhl.title.8135

Carpenter, F.M. 1966. The Lower Permian insects of Kansas: part 11. The orders Protorthoptera and Orthoptera. Psyche, 73(1):46-88.

Caudell, A.N. 1903. Notes on the nomenclature of Blattidae. Proceedings of the Entomological Society of Washington, 5:232-234.

Che, Y., Gui, S., Lo, N., Ritchie, A., and Wang, Z. 2017. Species delimitation and phylogenetic relationships in ectobiid cockroaches (Dictyoptera, Blattodea) from China. PLoS ONE, 12(1):e0169006. doi:10.1371/journal.pone.0169006
Cockerell, T.D.A. 1920. Fossil arthropods in the British Museum. The Annals and Magazine of Natural History, 5:273-279.

Deitz, L., Nalepa, C.A., and Klass K.D. 2003. Phylogeny of the Dictyoptera re-examined (Insecta). Entomologische Abhandlungen, 61:69-91.

Djernæs, M., Klass, K.D., Picker, M.D., and Damgaard, J. 2012. Phylogeny of cockroaches (Insecta, Dictyoptera, Blattodea), with placement of aberrant taxa and exploration of out-group sampling. Systematic Entomology, 37:65-83. doi:10.1111/j.1365-3113.2011.00598.x

Djernæs, M., Klass, K.D., and Eggleton, P. 2015. Identifying possible sister groups of Cryptocercidae+lsoptera: A combined molecular and morphological phylogeny of Dictyoptera. Molecular Phylogenetics and Evolution, 84:284-303. doi:10.1016/j.ympev.2014.08.019

Evangelista, D.A., Chan, K., Kaplan, K.L., Wilson, M.M., and Ware, J.L. 2015. The Blattodea s.s. (Insecta, Dictyoptera) of the Guiana Shield. Zookeys, 475:3787. doi:10.3897/zookeys.475.7877

Evangelista, D.A., Sylvain, E., Mendoza, C.M., and Guzman, K. 2016. New and enigmatic cockroaches (Insecta: Dictyoptera: Blattodea) of Guyana. The Journal of Natural History. doi:10.1080/00222933.2016.119364710.1080/ 00222933.2016 .1193647

Failla, M.C. and Messina, A. 1981. Una nuova specie de Ectobius de Sicilia e redescrizione di Ectobius aeineus Ramme (Insecta, Blattaria, Ectobiidae). Animalia, Catania, 8(1-3):43-49.

Germar, E.F. and Berendt, G.C. 1856. Die im Bernstein befindlichen Hemipteren und Orthopteren der Vorwelt. Die in Bernstein Befindlichen Organischen Reste der Vorwelt Gesammelt in Verbindung mit Mehreren Bearbeitetet und Herausgegeben, 2:1-40.

GIMP Team. 2016. Gnu Image Manupulation Software. https://www.gimp.org

Gomez, B., Martin-Closas, C., Barale, G., Sole de Porta, N., Thevenard, F., and Guignard, G. 2002. Frenelopsis (Coniferales: Cheirolepidiaceae) and related male organ genera from the lower cretaceous of Spain. Paleontology, 45:997-1036.

Gorokhov, A.V. 2007. New and little known orthopteroid insects (Polyneoptera) from fossil resins: Communication 2. Paleontological Journal, 41:156-166. doi:10.1134/s0031030107020062

Grambast, L. 1968. Evolution of the utricle in the charophyte genera Perimneste Harris and Atopochara Peck. Botanical Journal of the Linnaean Society, 61(384):5-11.

Grandcolas, P. 1996. The phylogeny of cockroach families: a cladistic appraisal of morpho-anatomical data. Canadian Journal of Zoology, 74:508-527.

Grimaldi, D. and Engel, M.S. 2005. Evolution of the Insects. Cambridge University Press, Cambridge, UK. 
Grimaldi, D.A., Shedrinsky, A., Ross, A., and Baer, N.S. 1995. Forgeries of fossils in "amber": history, identification and case studies. Curator, 37:251-274.

Guan, Z., Prokop, J., Roques, P., Lapeyrie, J., and Nel, A. 2016. Revision of the enigmatic insect family Anthracoptilidae enlightens the evolution of Palaeozoic stem-dictyopterans. Acta Palaeontologica Polonica, 61:71-87.

doi:10.4202/app.00051.201410.4202/ app.00051.2014

Gurney, A. 1951. Review: Classification of the Blattaria as indicated by their wings (Orthoptera). Entomological News, 62:202-207.

Gutierrez, E. and Perez-Gelabert, D. 2000. Annotated checklist of hispaniolan cockroaches. Transactions of the American Entomological Society, 126:433-446.

Handlirsch, A. 1906. Revision of American Paleozoic insects. Proceedings of the United States National Museum, 29(1441):661-820.

Handlirsch, A. 1925. Geschichte, litteratur, technik, palaontologie, phylogenie und systematik der Insecten. Handbuch der Entomologie, 3:1-1201.

Hebard, M. 1916. A new genus, Cariblatta, of the group Blattellites (Orthoptera, Blattidae). Transactions of the American Entomological Society, 42:147-186.

Hebard, M. 1917. The Blattidae of North America north of the Mexican boundary. Memoirs of the American Entomological Society, 2:1-284.

Inoue, J., Donoghue, P.C., and Yang, Z. 2010. The impact of the representation of fossil calibrations on Bayesian estimation of species divergence times. Systematic Biology, 59:74-89. doi:10.1093/sysbio/syp078

Inward, D., Beccaloni, G., and Eggleton, P. 2007. Death of an order: a comprehensive molecular phylogenetic study confirms that termites are eusocial cockroaches. Biology Letters, 3:331-335. doi:10.1098/rsbl.2007.0102

Jell, P.A. and Duncan, P.M. 1986. Invertebrates, mainly insects, from the freshwater, Lower Cretaceous, Koonwarra Fossil Bed (Korumburra group), South Gippsland, Victoria. Memoirs of the Association of Australasian Palaeontologists, 3:111-205.

Kambhampati, S., Luykx, P., and Nalepa, C.A. 1996. Evidence for sibling species in Cryptocercus punctulatus, the wood roach, from variation in mitochondrial DNA and karyotype. Heredity, 76:485-496.

Kedves, M. 1982. The geology of the Menat basin, France. Palaeontographica Abteilung B Palaophytologie, 182:87-150.

Kedves, M. and Russell, D.E. 1982. Palynology of the Thanetian layers of Menat. The geology of the Menat Basin, France. Palaeontographica B, 182:87-150.

Kjer, K.M., Ware, J.L., Rust, J., Wappler, T., Lanfear, R., Jermiin, L.S., Zhou, X., Aspöck, H., Aspöck, U., Beutel, R.G., Blanke, A., Donath, A., Flouri, T., Frandsen, P.B., Kapli, P., Kawahara, A.Y., Letsch, H., Mayer, C., McKenna, D.D., Meusemann, K., Niehuis, O., Peters, R.S., Wiegmann, B.M., Yeates, D.K., Reumont,
B.M.v., Stamatakis, A., and Misof, B. 2015. Response to comment on "Phylogenomics resolves the timing and pattern of insect evolution". Science, 349:487.

Klass, K.D. 1997. The external male genitalia and the phylogeny of Blattaria and Mantodea. Bonner Zoologische Monographien, 42:1-340.

Klass, K.D. 2001. Morphological evidence on blattarian phylogeny: "phylogenetic histories and stories" (Insecta, Dictyoptera). Berliner Entomologische Zeitschrift, 48:223-265.

Klass, K.D. and Meier, R. 2006. A phylogenetic analysis of Dictyoptera (Insecta) based on morphological characters. Entomologische Abhandlungen, 63:3-50.

Kukalova-Peck, J. and Lawrence, J.F. 2004. Relationships among coleopteran suborders and major endoneopteran lineages: Evidence from hind wing characters. European Journal of Entomology, 101:195-144.

Lacasa Ruiz, A. and Martínez-Delclòs, X. 1986. Meiatermes, Nuevo Género Fósil de Insecto Isóptero (Hodotermitidae) de las Calizas Neocomienses del Montsec (Provincia de Lérida, España). Institut d'Estudis llerdencs, Lleida, España.

Lee, S.-W. 2016. Taxonomic diversity of cockroach assemblages (Blattaria, Insecta) of the Aptian Crato Formation (Cretaceous, NE Brazil). Geologica Carpathica, 67(5):433-450. doi:10.1515/geoca-2016-0027

Legendre, F., Nel, A., Svenson, G.J., Robillard, T., Pellens, R., and Grandcolas, P. 2015. Phylogeny of Dictyoptera: dating the origin of cockroaches, praying mantises and termites with molecular data and controlled fossil evidence. PLOS ONE, 10(7):e0130127. doi:10.1371/journal.pone.0130127

Lopes, S.M. and Da Silva, L.d.O.C. 2013. A new species of Dendroblatta Rehn, 1916 from northern Brazil (Blattaria: Ectobiidae) collected in wasp nests. Zootaxa, 3599:597-600. doi:10.11646/zootaxa.3599.6.9

Maekawa, K., Lo, N., Kitade, O., Miura, T., and Matsumoto, T. 1999. Molecular phylogeny and geographic distribution of wood-feeding cockroaches in East Asian Islands. Molecular Phylogenetics and Evolution, 13:360-376.

Maekawa, K., Lo, N., Rose, H.A., and Matsumoto, T. 2003. The evolution of soil-burrowing cockroaches (Blattaria: Blaberidae) from wood-burrowing ancestors following an invasion of the latter from Asia into Australia. Proceedings of the Royal Society of London B: Biological Sciences, 270:1301-1307. doi:10.1098/rspb.2003.2359

Martin-Closas, C. and Lopez-Moron, N. 1995. The charophyte flora, p. 29-31. In Martinez-Delclos, X. (ed.), II International Symposium on Lithographic Limestones Field Trip Book. Institut d'Estudis Ilerdencs, Lerida.

Martinez-Delclos, X. 1990. Insectos del Cretacico inferior de Santa Maria de Meia (Llieda): coleccion Luis 
Maria Vidal i Carreras. Treballs del Museu de Geologia de Barcelona, 1:91-116.

Martinez-Delclos, X. 1993. Blátidos (Insecta, Blattodea) del Cretácico Inferior de España. Familias Mesoblattinidae, Blattulidae y Poliphagidae. Boletín Geológico y Minero, 104:516-538.

McKittrick, F.A. 1964. Evolutionary Studies of Cockroaches. Cornell University, Ithaca, New York.

Meunier, F. 1921. Die insektenreste aus dem Lutetien von Messel bei Darmstadt. Abhandlungen der Hessischen Geologischen Landesanstalt zu Darmstadt, 7:2-15.

Misof, B., Liu, S., Meusemann, K., Peters, R.S., Donath, A., Mayer, C., Frandsen, P.B., Ware, J., Flouri, T., Beutel, R.G., Niehuis, O., Petersen, M., IzquierdoCarrasco, F., Wappler, T., Rust, J., Aberer, A.J., Aspock, U., Aspock, H., Bartel, D., Blanke, A., Berger, S., Bohm, A., Buckley, T.R., Calcott, B., Chen, J., Friedrich, F., Fukui, M., Fujita, M., Greve, C., Grobe, P., Gu, S., Huang, Y., Jermiin, L.S., Kawahara, A.Y., Krogmann, L., Kubiak, M., Lanfear, R., Letsch, H., Li, Y., Li, Z., Li, J., Lu, H., Machida, R., Mashimo, Y., Kapli, P., McKenna, D.D., Meng, G., Nakagaki, Y., Navarrete-Heredia, J.L., Ott, M., Ou, Y., Pass, G., Podsiadlowski, L., Pohl, H., von Reumont, B.M., Schutte, K., Sekiya, K., Shimizu, S., Slipinski, A., Stamatakis, A., Song, W., Su, X., Szucsich, N.U., Tan, M., Tan, X., Tang, M., Tang, J., Timelthaler, G., Tomizuka, S., Trautwein, M., Tong, X., Uchifune, T., Walzl, M.G., Wiegmann, B.M., Wilbrandt, J., Wipfler, B., Wong, T.K., Wu, Q., Wu, G., Xie, Y., Yang, S., Yang, Q., Yeates, D.K., Yoshizawa, K., Zhang, Q., Zhang, R., Zhang, W., Zhang, Y., Zhao, J., Zhou, C., Zhou, L., Ziesmann, T., Zou, S., Li, Y., Xu, X., Zhang, Y., Yang, H., Wang, J., Wang, J., Kjer, K.M. and Zhou, X. 2014. Phylogenomics resolves the timing and pattern of insect evolution. Science, 346:763767.

doi:10.1126/science. 1257570

Murienne, J. 2009. Molecular data confirm family status for the Tryonicus-Lauraesilpha group (Insecta: Blattodea: Tryonicidae). Organisms Diversity \& Evolution, 9:44-51.

doi:10.1016/j.ode.2008.10.005

Nel, A. 2008. The oldest bee fly in the french Paleocene (Diptera: Bombyliidae). Comptes Rendus Palevol, 7:401-405.

Nel, A., Prokop, J., and Kirejtshuk, A.G. 2014. The beetlelike Palaeozoic and Mesozoic roachoids of the socalled "umenocoleoid" lineage (Dictyoptera: Ponopterixidae fam. nov.). Comptes Rendus Palevol, 13:545-554.

Parham, J.F., Donoghue, P.C., Bell, C.J., Calway, T.D., Head, J.J., Holroyd, P.A., Inoue, J.G., Irmis, R.B., Joyce, W.G., Ksepka, D.T., Patane, J.S., Smith, N.D., Tarver, J.E., van Tuinen, M., Yang, Z., Angielczyk, K.D., Greenwood, J.M., Hipsley, C.A., Jacobs, L., Makovicky, P.J., Muller, J., Smith, K.T., Theodor, J.M., Warnock, R.C., and Benton, M.J. 2012. Best practices for justifying fossil calibrations. Systematic Biology, 61:346-359.

doi:10.1093/sysbio/syr107

Pellens, R., D'Haese, C.A., Belles, X., Piulachs, M.D., Legendre, F., Wheeler, W.C., and Grandcolas, P. 2007. The evolutionary transition from subsocial to eusocial behaviour in Dictyoptera: phylogenetic evidence for modification of the "shift-in-dependentcare" hypothesis with a new subsocial cockroach. Molecular Phylogenetics and Evolution, 43:616-626. doi:10.1016/j.ympev.2006.12.017

Piton, L.E. 1940. Paléontologie du Gisement Éocène de Menat (Puy-de-Dôme) (Flore et Faune). Imprimeries P. Vallier, France.

Poda, N. 1761. Insecta Musei Graecensis, quae in ordines genera et species juxta systema naturae Caroli Linnaei. Graz, Austria.

Pongracz, A. 1935. Die eozane insektenfauna des Geiseltales. Nova acta Leopoldina, Abhandlungen der Kaiserlich Leopoldinisch-Carolinisch Deutschen Akademie der Naturforscher, herausgegeben und redigiert im Namen der Kaiserlich Leopoldinisch-Carolinisch Deutschen Akademie der Naturforscher, 2:485-572.

Princis, K. 1960. Zur systematik der Blattarien. Eos, 36:427-449.

Princis, K. 1962. Blattariae: Subordo Polyphagoidea: Fam. Polyphagidae. Orthopterum Catalogus. W. Junk, 's-Gravenhage, The Netherlands.

Princis, K. 1963. Orthopterum Catalogus. W. Junk, 'sGravenhage, The Netherlands.

Ramme, W. 1923. Vorarbeiten zu einer monographie des blattiden genus Ectobius Stephens. Archiv für Naturgeschiste, 89A(7):97-145.

Ramme, W. 1927. Die Dermapteren und Orthopteren Siziliens und Kretas. Eos: Revista española de Entomología, 3:111-200.

Rehn, J.A. and Hebard, M. 1927. The Orthoptera of the West Indies number 1. Blattidae. Bulletin of the American Museum of Natural History, 54:1-320.

Rehn, J.W.H. 1951. Classification of the Blattaria as indicated by their wings (Orthoptera). Memoirs of the American Entomological Society, 14:1-134.

Rocha e Silva, I. 1955. Sobre uma nova especie de "Cariblattoides" Hebard, 1927 (Blattidae, Pseudomopinae). Revista Brasileira Biologia, 15(1):79-82.

Ross, A.J. 2012. Testing decreasing variabililty of cockroach forewings through time using four recent species: Blattella germanica, Polyphaga aegyptiaca, Shelfordella lateralis and Blaberus craniifer, with implications for the study of fossil cockroach forewings. Insect Science, 19:129-142. doi:10.1111/j.1744-7917.2011.01465.x

Roth, L.M. 1970. The male genitalia of Blattaria. IV. Blaberidae: Blaberinae. Psyche, 77:308-342.

Roth, L.M. 1977. A taxonomic revision of the Panesthiinae of the World I. The Panesthiinae of Australia (Dictyoptera: Blattaria: Blaberidae). Australian Journal of Zoology, 48:1-112. 
Roth, L.M. 1995. Africalolampra ehrmanni new genus and species, and the male of Paraplecta parva Princis (Blattaria: Blaberidae). Psyche, 102:89-98.

Roth, L.M. 1996. The cockroach genera Anaplecta, Anaplectella, Anaplectoidea, and Malaccina (Blattaria, Blattellidae: Anaplectinae and Blattellinae). Oriental Insects, 30:301-372.

Roth, L.M. 2002. The genus Ischnoptera Burmeister. I. The darlingtoni-species-group, with seven new species (Blattaria: Blattellidae, Blattellinae). Transactions of the American Entomological Society, 128:109-131.

Roth, L.M. and Willis, E.R. 1957. An analysis of oviparity and viviparity in the Blattaria. Transactions of the American Entomological Society, 83:221-238.

Saussure, H.d. 1864. Orthopteres - Blattides. Mémoires pour Servir L'Histoire Naturelle du Mexique, des Antilles et des Etats-Unis, 4:5-279.

Scudder, S.H. 1890. The Tertiary insects of North America, United States. Geological and Geographical Survey of the Territories. v. 13. doi:10.5962/bhl.title.44698

Schneider, J. 1983. Die Blattodea (Insecta) des Paläozoikums. Teil 1: systematik, ökologie und biostratigraphyie. Freiberger Forschungshefte, 382:106-145.

Sendi, H. and Azar, D. 2017. New aposematic and presumably repellent bark cockroach from Lebanese amber. Cretaceous Research, 72:13-17. doi:10.1016/j.cretres.2016.11.013

Seoane, V.L. 1879. Description de deux orthoptères nouveaux d'Espagne. Mitteilungen der Schweizerischen Entomologischen Gesellschaft, 5:485-487.

Shelford, R. 1911. The British Museum collection of Blattidae enclosed in amber. Journal of the Linnean Society, Zoology, 32:59-69.

Shelford, R. 1910. On a collection of Blattidae preserved in amber, from Prussia. Journal of the Linnean Society of London, Zoology, 30:336-355.

Silva-da-Silva, L.R. and Lopes, S.M. 2015. Two new species of Xestoblatta Hebard, 1916 from Brazil, a redescription of Xestoblatta roppai Rocha e Silva Albuquerque \& Fraga, 1975 and a key for the species of the buscki group (Blattodea, Ectobiidae, Blattellinae). Zookeys, 526:117-129. doi:10.3897/zookeys.526.6077

Šmídová, L. and Lei, L. 2017. The earliest amberrecorded type cockroach family was aposematic (Blattaria: Blattidae). Cretaceous Research, 72:18999.

Smith, M.E., Carroll, A.R., and Singer, B.S. 2008. Synoptic reconstruction of a major ancient lake system: Eocene Green River Formation, western United States. Geological Society of America Bulletin, 120:54-84. doi:10.1130/b26073.1

Stål, C. 1877. Orthoptera nova ex Insulis Philippines descriptsit. Ofversigt af Kongelige Vetenskaps-Akademiens Forhandlingar, 34(10):33-60.
Statz, G. 1939. Geradflügler und Wasserkäfer der oligocänen Ablagerungen von Rott. Decheniana, 99:1102.

Stephens, J.F. 1835. Illustrations of British Entomology; or, a Synopsis of Indigenous Insects: Containing their Generic and Specific Distinctions; with an Account of their Metamorphoses, Times of Appearance, Localities, Food, and Economy, as far as Practicable. Baldwin and Cradock, London. doi:http://dx.doi.org/10.5962/bhl.title.8133.

Stroiński, A. and Szwedo, J. 2012. The oldest known Lophopidae planthopper (Hemiptera: Fulgoromorpha) from the European Palaeocene. Geobios, 45:413-420. 10.1016/j.geobios.2011.10.007

Thorne, B.L. and Carpenter, J.M. 1992. Phylogeny of Dictyoptera. Systematic Entomology, 17:253-268.

Tong, K.J., Duchêne, S., Ho, S.Y.W., and Lo, N. 2015. Comment on "Phylogenomics resolves the timing and pattern of insect evolution." Science, 349:487.

Uvarov, B.P. 1940. Twenty-eight new generic names in Orthoptera. Annals and Magazine of Natural History, 5(11):173-176.

Vidlička, L'. 2013. New species of Macrophyllodromia (Blattaria, Blattellidae) from Ecuador and a key to males of the genus. Zootaxa, 3635:185. doi:10.11646/zootaxa.3635.2.6

Vincent, P.M., Aubert, M., Boivin, P., Cantagrel, J.M., and Lenat, J.F. 1977. Découverte d'un volcanisme paléocène en Auvergne: les maars de Menat et leurs annexes; Etude géologique et géophysique. Bulletin de la Société géologique de France, 5:1057-1070.

Vishnyakova, V.N. 1964. Osovennosti zhilkovaniya perednikh kryl'ev novogo pozdneyurskogo tarakana. Paleontologischeskii Zhurnal, 1:82-87.

Vishnyakova, V.N. 1982. Jurassic cockroaches of the new family Blattulidae from Siberia. Paleontological Journal, 16(2):67-77.

Vršanský, P. 1997. Piniblattella gen. nov. - the most ancient genus of the family Blattellidae (Blattodea) from the Lower Cretaceous of Siberia. Entomological Problems, 28:67-79.

Vršanský, P. 1999. Two new species of Blattaria (Insecta) from the Lower Cretaceous of Asia, with comments on the origin and phylogenetic position of the families Polyphagidae and Blattulidae. Entomological Problems, 30:85-91.

Vršanský, P. 2000. Decreasing variability - from the Carboniferous to the present! (validated on independent lineages of Blattaria). Paleontological Journal, 34(3):S374-S379.

Vršanský, P. 2002. Origin and the early evolution of mantises. AMBA Projekty, 6(1):1-16.

Vršanský, P. 2004. Cretaceous gondwanian cockroaches (Insecta: Blattaria). Entomological Problems, 34:4954.

Vršanský, P. 2005. Lower Cretaceous cockroaches and mantids (Insecta: Blattaria, Mantodea) from the Sharin-Gol in Mongolia. Entomological Problems, 35(2):163-167. 
Vršanský, P. 2007. Jumping cockroaches (Blattaria, Skokidae fam. $n$ ) from the Late Jurassic of Karatau in Kazakhstan. Biologia Bratislava, 62(5):588-592.

Vršanský, P. 2008. New blattarians and a review of dictyopteran assemblages from the Lower Cretaceous of Mongolia. Acta Palaeontologica Polonica, 53:129136.

Vršanský, P., Liang, J.H., and Ren, D. 2009. Advanced morphology and behaviour of extinct earwig-like cockroaches (Blattida: Fuziidae fam. nov.). Geologica Carpathica, 60(6):449-462.

Vršanský, P. 2009. Albian cockroaches (Insecta, Blattida) from french amber of Archingeay. Geodiversitas, 31:73-98.

Vršanský, P. 2010. Cockroach as the earliest eusocial animal. Acta Geologica Sinica, 84:793-808.

Vršanský, P. and Anisyutkin, L.N. 2008. Cockroaches \& mantises descriptions, p. 199-209. In Krassilov V. and Rasnitsyn A. (eds.), PlantArthropod Interactions in the Early Angiosperm History: Evidence from the Cretaceous of Israel. Pensoft. Sofia, Bulgaria.

Vršanský, P. and Ansorge, J. 2001. New Lower Cretaceous polyphagid cockroaches from Spain (Blattaria, Polyphagidae, Vitisminae subfam. nov.). Cretaceous Research, 22:157-162. doi:10.1006/cres.2000.0244

Vršanský, P. and Aristov, D.S. 2012. Enigmatic Late Permian cockroaches from Isady, Russia (Blattida: Mutoviidae fam. n). Zootaxa, 3247:19-31.

Vršanský, P. and Bechly, G. 2015. New predatory cockroaches (Insecta: Blattaria: Manipulatoridae fam. n.) from the Upper Cretaceous Myanmar amber. Geologica Carpathica, 66:133-138.

Vršanský, P., Liang, J.-H., and Ren, D. 2009. Advanced morphology and behaviour of extinct earwig-like cockroaches (Blattida: Fuziidae fam. nov.). Geologica Carpathica, 60:10. doi:2478/v10096-009-0033-0

Vršanský, P., Oružinský, R., Barna, P., Vidlička, L., and Labandeira, C.C. 2014. Native Ectobius (Blattaria: Ectobiidae) from the Early Eocene Green River Formation of Colorado and its reintroduction to North America 49 million years later. Annals of the Entomological Society of America, 107:28-36. doi:10.1603/an13042

Vršanský, P.V., Smidova, L., Valaska, D., Barna, P., Vidlička, L., Takac, P., Pavlik, L., Kudelova, T., Karim, T.S., Zelagin, D., and Smith, D. 2016. Origin of origami cockroach reveals long-lasting (11 Ma) phenotype instability following viviparity. Naturwissenschaften, 103:78. doi:10.1007/s00114-016-1398-4
Vršanský, P., Vidlička, L., Barna, P., Bugdaeva, E., and Markevich, V. 2013. Paleocene origin of the cockroach families Blaberidae and Corydiidae: evidence from Amur River region of Russia. Zootaxa, 3635:117. doi:10.11646/zootaxa.3635.2.2

Vršanský, P., Vidlička, L.u., Čiampor, Jr., F., and Marsh, F. 2012. Derived, still living cockroach genus Cariblattoides (Blattida: Blattellidae) from the Eocene sediments of Green River in Colorado, USA. Insect Science, 19:143-152. doi:10.1111/j.1744-7917.2010.01390.x

Walker, F. 1869. Catalogue of the Specimens of Dermaptera Saltatoria and Supplement to the Blattariae in the Collection of the British Museum. Trustees of the British Museum, London. doi:10.5962/bhl.title.8149

Wang, Z., Wu, K., and Che, Y. 2013. New record of the cockroach genus Pseudophoraspis (Blaberidae, Epilamprinae) from China with descriptions of three new species. Zookeys, 273:1-14.

doi:10.3897/zookeys.273.41221-14. 10.3897/zookeys. 273.4122

Wappler, T., Currano, E.D., Wilf, P., Rust, J., and Labandeira, C.C. 2009. No post-Cretaceous ecosystem depression in European forests? Rich insect-feeding damage on diverse middle Palaeocene plants, Menat, France. Proceedings: Biological Sciences, 276:4271-4277. doi:10.1098/rspb.2009.1255

Ware, J.L., Grimaldi, D.A., and Engel, M.S. 2010. The effects of fossil placement and calibration on divergence times and rates: an example from the termites (Insecta: Isoptera). Arthropod Structure and Development, 39:204-219. doi:10.1016/j.asd.2009.11.003

Wappler, T., Guilbert, E., Labandeira, C.C., Hornschemeyer, T., and Wedmann, S. 2015. Morphological and behavioral convergence in extinct and extant bugs: the systematics and biology of a new unusual fossil lace bug from the Eocene. PLoS ONE, 10(8):e0133330. doi:10.1371/journal.pone.0133330

Ware, J.L., Litman, J., Klass, K.D., and Spearman, L.A. 2008. Relationships among the major lineages of Dictyoptera: the effect of outgroup selection on dictyopteran tree topology. Systematic Entomology, 33:429-450. doi:10.1111/j.1365-3113.2008.00424.x

Wolfram Research. Mathematica Edition: Version 9.1. Wolfram Research Inc., Champaign, Illinois, United States.

Yoshizawa, K. 2011. Monophyletic Polyneoptera recovered by the wing base structure. Systematic Entomology, 36:377-394. 


\section{APPENDIX 1.}

Character matrix of wing and tegmina characters. Taken from Rehn (1951). We read through the original document and extracted character data from the taxonomic keys and descriptions of taxa. When conflicting information was encountered, we recorded both accounts and noted the conflict with an "or" statement or with a "?". In some cases, character information was inferred and marked with a "?", but most often missing data was left blank. (Supplied as XLS file at palaeo-electronica.org/content/fc-10.) 
APPENDIX 2.

Comment on use of Rehn, JWH. (1951). "Classification of the Blattaria as indicated by their wings (Orthoptera)". Memoirs of the American Entomological Society. 14. 1-134

As his doctoral dissertation, John W.H. Rehn (not to be confused with J.A.G. Rehn, his father) did an extensive review of the wing and tegminal morphology of cockroaches. Given that fossil cockroaches are largely classified based on their wings, this publication is a major point of reference. However, cockroach wing morphology is currently known to give erroneous phylogenetic signal (Princis, 1960; Klass, 2001) and thus fossil classifications may suffer from this error. That is not to say that Rehn (1951) is not an important work. It is a major resource for wing morphology and it set many of the conventions used today. However, as we discuss below, the many errors in this paper make improper use of the work potentially misleading.

In historical context Rehn's paper was important, although perhaps not as influential as McKittrick (1964) or Princis (1963). At first it was received positively. Gurney (1951) reviewed Rehn (1951) and said, "Fundamentally, the classification which he offers appears to be very sound, and modifications which specialists will undoubtedly suggest will in no way detract from the basic value of the work or the regularity with which it will be consulted for many decades". However, soon the work's classifications were largely rejected (Princis, 1960; McKittrick, 1964) with some exception (for examples see [Roth and Willis 1957; Roth, $1977,1996])$. In the modern era, phylogenetic studies generally do not reference "Classification of the Blattaria as indicated by their wings" (Grandcolas, 1996; Maekawa et al., 1999; Deitz et al., 2003; Maekawa et al., 2003; Ware et al., 2008; Djernæs et al., 2012; Djernæs et al., 2015) with the exception of a single morphological character cited by Thorne and Carpenter (1992) or references to its illustrations (Klass and Meier, 2006).

The paper consists mainly of morphological descriptions of wings and tegmina at various taxonomic levels (superfamilies, families, subfamilies and tribes), and a series of wing and tegminal illustrations. Although the paper represents an exhaustive synthesis of data, much of the written work is unreliable. The language of the work is highly subjective, often vague and sometimes inconsistent. Illustrating all three of these points, the dissertation frequently refers to the length of the subcosta as simply "long" or "short". This is sometimes expanded upon by giving the subcostal length relative to wing length. However, references to a subcostal length equivalent to half the wing length are described as both "long" or "short" at different times. There are many other instances where the assertions about comparative morphology are often incorrect when simply cross referenced with other parts of this work (in particular see the examples at the end of this section). Finally, Klass and Meier (2006) point out that Rehn (1951) is unable to thoroughly define vein homologies because he omits detailed analysis of the wing base.

The characters described in the paper are infrequently uniformly distributed within the clades defined, and they are almost always plesiomorphic or homoplastic. Maybe most unfortunate of all, the paper fails to describe the state of many of characters in a large proportion of the taxa discussed ( $57 \%$ empty cells in Appendix 1 ).

Rehn did complete an extremely ambitious undertaking in his 1951 paper, and much of this contribution is still valuable. Many authors still use the terminology in Rehn (1951) for the wing and tegminal veins (e.g., Anisyutkin, 2008, 2014; Wang et al., 2014; Evangelista et al., 2016). The illustrations are a common point of reference and are reproduced in multiple works (e.g., Klass, 2001). However, relying solely on the written descriptions of wing venation can be misleading.

Below are only some of the errors and inconsistencies in "Classification of the Blattaria as indicated by their wings". "Conflicts" or "contradictions" refer to instances where the author made irreconcilable statements about the state of a morphological character in a taxon.

Holocompsinae - Contradiction between the key and the description. Key says they don't have psuedostigma on the wings but the description says they do.

Corydiinae - Numerous conflicting statements about the number of branches in the tegmina's media, regularity of the radius, and minimum number of anal veins in the wings.

Latindiinae - The description of the subfamily conflicts with the descriptions of the tribes it contains. The number of branches on R1 in the wings is unclear.

Latindiini - There is a conflict about the number of anal veins in the wings.

Compsodiini - Conflict in the number of anal veins in tegmina. 
Panesthiidae - Contradiction with earlier sections about the length of the anal area in tegmina and some other characters. The description contradicts itself about the maximum number of branches in the radial sector.

Nyctiborinae - Contradiction about the regularity of the radial veins.

Epilamprinae - Contradiction about the branching of the media vein, and the distance between p3 and the branched axillary.

Perisphaerini - Two contradictions (one with the previous description of Epilamprinae and one within the description) about the shape of the plical furrow of the tegmina. There are also contradictions about the shape of the anterior margin.

Nauphoetini - There is a conflict about the minimum number of branches on the branched axillary vein of the wings. It is also unclear if there is an apical posterior branch on the radius or not.
Panchlorini - There is a contradiction about the regularity of branches in the subcosta of tegmina.

Thoracini - There is a conflict in the number of branches in the branched axillary veins in the wings.

Parcoblattini - Many of the characters he discusses in other sections are completely missing from this description.

Eustegastini - Conflicting statements about the number of branches of the media of the wings.

Euandroblattini - Conflicting statements about the weight of the plical furrow in the tegmina.

Ischnopterini - Conflicting statements about the presence of apical radial rami of tegmina. There is a contradiction of terminology about the apical or anterior subcostal rami. Finally, a contradiction about the number of cubital veins going to the plical furrow tegmina.

Plectopterini - contradiction in the direction of the branches coming off of the fused media and cubitus of tegmina. 


\section{APPENDIX 3.}

Reflectance Transformation Image (RTI) of "Gyna" obesa (Piton, 1940). High resolution photographs with hemispherical lighting with a focus on the pronotum and thorax. Various light angles emphasize different ridges in the fossil and make it difficult to discern which path the posterior edge of the pronotum takes. The more posterior candidate for the edge of the pronotum could be sculpturing of the middle thoracic segment. The file can be viewed with RTI viewer 1.1.0 (http:// culturalheritageimaging.org/What_We_Offer/Downloads/View/) and RTI file available at palaeoelectronica.org/content/fc-10.

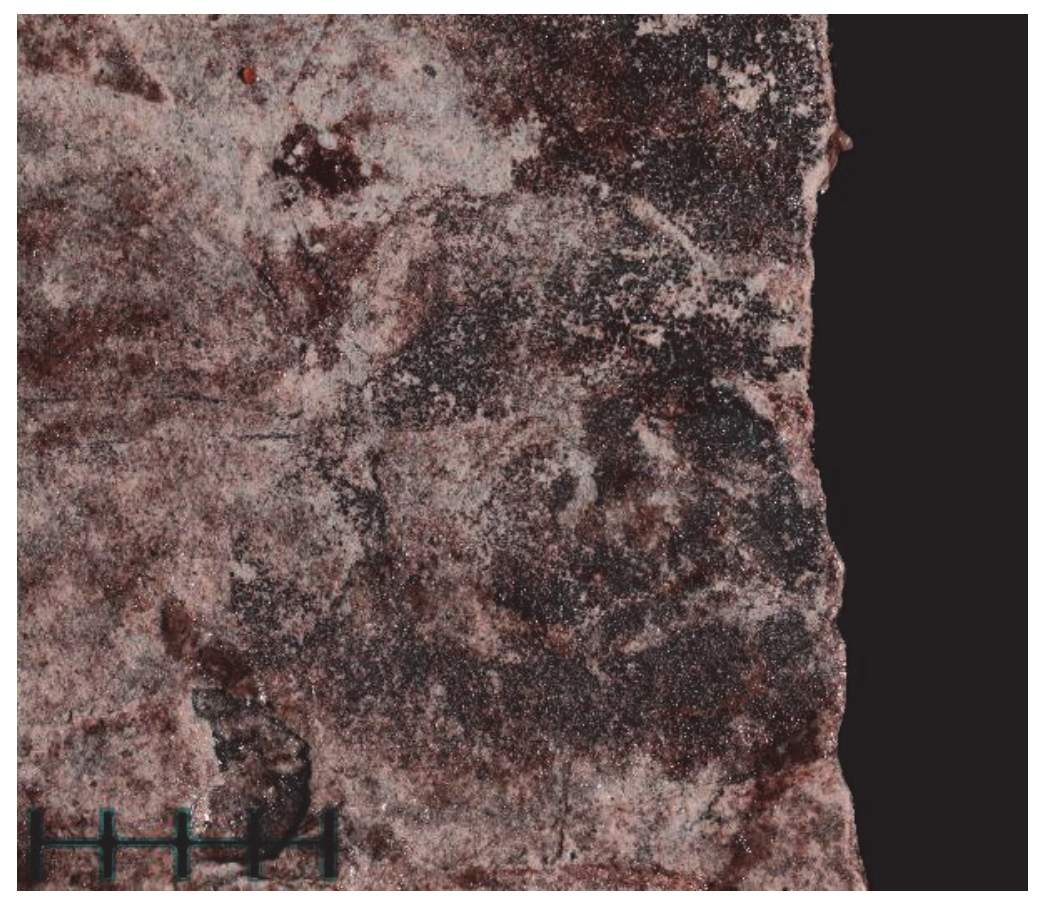




\section{APPENDIX 4.}

Fossil Blattodea s.s. from Fossil Works database. A list of fossil cockroaches based on the fossil works database (Alroy et al., 2016). The ages and phylogenetic determinations in the list are presented without our scrutiny. We discuss many of these fossils in the paper and consider many of them to be unreliable. (Available as xls file at palaeo-electronica.org/content/fc-10) 